\title{
An empirical characterization of the effects of public debt on economic growth
}

\author{
María del Carmen Ramos-Herrera \\ Colegio Universitario de Estudios Financieros, Universidad Complutense de Madrid, \\ Campus de Somosaguas, 28223 Madrid, Spain, madelram@ccee.ucm.es \\ Corresponding author: Simón Sosvilla-Rivero \\ Complutense Institute for International Studies, Universidad Complutense de Madrid, \\ Campus de Somosaguas, 28223 Madrid, Spain, sosvilla@ccee.ucm.es
}

\begin{abstract}
Based on a data set of 115 economies, this paper empirically investigates the relation between public debt and economic growth. Using the World Bank's classification for income groups, we initially find that those countries that present the lowest public debt are characterized by the highest economic growth, while the smallest growth rates are associated with the highest public debt. Nevertheless, this conclusion is tempered when we analyse the countries by income level: low-income countries have a different behaviour with respect to lower-middle, upper-middle and high income countries. When using the IMF's country classification, the results do not suggest a clear pattern in the public debt-economic growth nexus across different countries, but indicate a heterogeneous relationship between such key macroeconomic variables.
\end{abstract}

JEL classification numbers: C32, H63, O40, O57.

KEY WORDS: Public debt, economic growth. 


\section{Introduction}

Over the last two decades, considerable attention has been devoted to role of public debt in economic growth and, although there is a large body of theoretical and empirical literature devoted to this issue, the result are far from conclusive [see Panizza and Presbitero (2013) for a survey].

According to the conventional perspective, the increase of public debt to finance government deficit can stimulate aggregate demand and economic performance in the short-term, although when there is not a strict control of debt accumulation it could be possible to experience capital outflows and important output reduction in the long-term (Elmendorf and Mankiw, 1999). Some authors contend that in crisis periods, debtfinanced expansionary fiscal policies should be implemented to maintain welfare and promote economic growth [see for instance, Krugman (2011) or DeLong and Summers (2012)]. On the contrary, authors as Cochrane (2011) or Reinhart and Rogoff (2010), among others, indicate that higher levels of public debt reduce significantly the economic performance and for this reason, austerity policies should be preferred to guarantee the confidence of economic agents and to improve their expectations. Indeed, few macroeconomic policy debates have generated as much controversy as the current austerity argument [see Alesina and Ardagna (2010), Alesina et al. (2015), Guajardo et al. (2014) or Jordà and Taylor (2016)] and, as Europe stagnates, the polemic appears to be far from over.

The purpose of this paper is to contribute to the literature by performing a fresh and comprehensive assessment of this hypothesis in a large cross-section of countries over a long sample. The key questions that guide our analysis are: (i) is economic growth affected by the level of public debt? and (ii) does it depend upon the income level? Answers to these questions seem relevant as they have direct implications for policy makers and academic researchers.

The paper is organised as follows. Section II briefly reviews the empirical literature on public debt and economic growth. Section III details the data. Section IV describes the empirical strategy and reports the results. Section V offers some concluding remarks. 


\section{Literature Review}

The conventional view is that while debt can stimulate aggregate demand and output in the short run [see Barro (1990) or Elmendorf and Mankiw (1999)], it may crowd out capital and reduce output in the long run (Diamond, 1965; Modigliani, 1961; Salotti and Trecoci, 2016). Moreover, the literature provides different reasons to explain why the negative effects of public debt are likely to increase, the higher the public debt level is. Gale and Orzag (2003) and Baldacci and Kumar (2010) argue that high public debt can adversely affect capital accumulation and growth via higher long-term interest rates. Barro (1979) and Dotsey (1994) points out the role played by higher future distortionary taxation. Sargent and Wallace (1981), Cochrane (2011) and Barro (2013) emphasize the significant negative effect of debt-induced inflation on economic growth. Nevertheless, some endogenous growth models show that a positive impact may be possible in the short-run, depending on the type of public goods financed out of debt (Aizenman et $a l ., 2007)$ or up to certain limits when debt is used to finance productive public capital (Aschauer, 2000).

Focusing on empirical studies there is still no consensus on the relationship between these two variables. Using a lag distributional model on nine Latin American countries over twelve years, Geiger (1990) finds that debt burden implies an important reduction on economic growth. Considering different exchange rate arrangement, political systems, institutions and historic contexts, Reinhart and Rogoff (2010 and 2011) study one of the most enlarged database including forty-four countries over two hundred years. Focusing directly on total public debt (domestic and external), they identify a weak relationship between gross central government debt and real Gross Domestic Product (GDP) growth when debt is below 90 percent of GDP, nevertheless once it exceeds this threshold ${ }^{1}$ economic growth slows significantly. In fact, above this threshold, the median economic growth decreases by one percent and the average economic growth falls almost four percent with respect to the lower burden groups. When they focus on external debt (public plus private debt), their results suggest that above 60 percent of GDP, annual economic growth reduces almost two percent and for higher levels of debt growth rates diminish approximately in half. In the same vein,

\footnotetext{
1 The threshold used by them for public debt in advanced and emerging economies is similar.
} 
Caner et al. (2010) obtain a similar non-linearity effect on growth, since they state that above 77 percent of GDP additional debt affects negatively output growth, however for moderate levels of public debt contribute to increase investment and get faster economic growth. Cecchetti et al. (2011) examine the impact of debt on economic growth using data for 18 Organisation for Economic Co-operation and Development (OECD) countries from 1980 to 2010 . Their results support the view that, beyond the $85 \%$ of GDP, public debt is bad for growth.

Authors as Rangarajan and Srivastava (2005) or Kannan and Singh (2007) reveal a long run relationship between these two variables and to be more specific using Johansen cointegration techniques identify some adverse effects in the case of high levels of public debt. Applying the autoregressive distributed lag model and the error correction model in India during 1980 to 2010, Bal and Rath (2014) illustrate that government debt affects negatively to economic growth in the short and also in the long term. Ismihan and Ozkan (2012) study how financial development can influence on the macroeconomic outcomes. They detect that the lower the financial development, more relevant will be the unfavorable effects of public debt on the economy. Qureshi and Ali (2010) empirically explored the impact of high public debt burden on the economy of Pakistan. The sample of the study was 1981 to 2008. From their study a vast negative impact of public debt on the economy of Pakistan had been found by the authors.

Presbitero (2012) detects a different behavior for developing countries. In this case, higher public debt implies lower economic growth up to a threshold of 90 percent of GDP, however from this magnitude it has not effect on the dependent variable [a similar conclusion arises in Cordella et al. (2010) with external debt]. This non-linear effect is explained by the author by country-specific factors, because the highest level of debt should be related to sound macroeconomic policies and confident and stable institutional framework. On the contrary, Abbas and Christensen (2010) using a panel data of low-income and emerging countries, describe a positive contribution to economic growth when domestic debt presents moderate levels, nevertheless once represents more than 35 percent of bank deposits has a negative impact on growth due to inflationary pressures and the crowding out of private sector. 
Instead of applying a descriptive analysis as in Reinhart and Rogoff (2010 and 2011), Égert (2015) uses nonlinear threshold models based on a similar database to identify the debt threshold beyond which negative effects for economic growth start to appear. This paper highlights that nonlinear effects are very sensitive to data frequency, time and country dimension and other assumptions. The formal econometric test shows that the threshold can be lower than 90 percent, even between 20 and 60 percent of GDP. In fact, these results are maintained when it is used a multivariate model including traditional explanatory factors of long-term economic growth in a context of uncertainty.

Applying a dynamic threshold model for the debt-growth nexus, Baum, ChecheritaWestphal and Rother (2013) study the short-term impact of debt on the economic growth in 12 euro area economies during 1990 to 2010. They identify a positive effect below $67 \%$ and above $95 \%$, showing a negative consequence on the economic activity. Minea and Parent (2012) implement some endogeneous thresholds estimation techniques and obtain a similar result: at lower levels of debt, an increase in the deficit spending can generate an increment in the economic performance, nevertheless at higher levels can reduce the economic growth substantially.

Trying to avoid the problem of endogeneity, since it is possible to have a bi-directional causality between these two variables, Kumar and Woo (2015) achieve a linear relationship for 38 advanced and emerging countries for a much shorter time horizon, showing that when public debt increase in a 10 percent the annual per capita real GDP growth experiments a fall of 0.2 percentage points. In the same line, Schclarek (2005) shows no evidence of an inverted U-shape in 59 developing countries for more than 30 years, however finds that foreign debt accumulation decreases per capita output growth in a linear way. Similar results have been reached when a panel of 152 developing economies over the period 1977-2002 is analyzed in Presbitero (2005). Although debt service is not significant across any specification in this paper, debt stock indicators are always significant displaying an adverse impact on economic growth. In fact, the negative effect ranges between 1.02 to 1.50 for the deb-to-GDP ratio using different specifications. On average, an increase of 10 percent of external debt reduces economic growth by 0.11 . This effect is stronger in low-income countries. The transmission channels through which this author justifies the negative linear relationship between 
external debt and economic performance is the liquidity constraint, the macroeconomic instability due to uncertainty, lower efficiency of investment and its effect on macroeconomic policies and institutional development. A similar argument is used by Pattillo et al. (2011) to explain how high levels of external debt diminish economic growth along different robust econometric methodologies since instead of reducing the investment volume it goes down the efficiency of it.

Chudik et al. (2013) examine the long-term effects of public debt on growth employing a cross-sectionally augmented distributed lag methodology. These authors emphasize that the results would depend whether the increase of debt is permanent or temporary (to smooth out business cycle fluctuations), since only if it is permanent it will notice the negative impact on growth in the long-term. They indicate that after periods characterized by high levels of debt, it is possible to implement a fiscal policy compatible with Keynesian deficit spending, but it must be accompanied by credible announcements of reducing the debt burden to levels considered as normal. One of the main limitations of this paper is the absence of a specific estimation of this turning point in which there is no credible expectations of a reversal in the debt pattern.

Most of the authors focus mainly on the impact of indebtedness on economic growth, disregarding the possibility of a reverse causality running from growth to debt. To fill this gap in the literature, some papers have studied the causal relationship between these two variables. However, there is currently no consensus among economist in this area. For instance, Ferreira (2009) find a bi-directional causal relationship between public debt and growth when analyze 20 countries members of the OECD during thirteen years. Applying a different methodology (instrumental approach), Panizza and Presbitero (2014) do not detect a causal connection. In the same line, Puente-Ajovín and Sanso-Navarro (2015) show that government debt does not cause real GDP growth using a panel bootstrap Granger causality test in 16 OECD countries from 1980 to 2009. In contrast, their paper supports the idea that non-financial private debt affect to real economic performance. More recently, examining eleven peripheral and central EMU countries, Gómez-Puig and Sosvilla-Rivero (2015) confirm that there is not a negative causation between sovereign debt and economic growth when they consider the whole sample period (1980-2013). Nevertheless, they find an inverse Granger-causality 
relationship from 2007 or $2009^{2}$ to the end of the period above a debt threshold that ranges from 56 to $103 \%$. This paper suggests that an increase in public indebtedness would reduce economic growth.

As can be seen from this concise literature review, the theoretical models provide ambiguous results and rather than many papers have found a negative correlation between public debt and economic growth in the long-run for advanced countries, Panizza and Presbitero (2013) claim that is not a robust result because small changes in data or in the econometric methods yield different results with respect to the causal relationship between these two variables. These authors emphasize the relevance of the definition of public debt and the role of cross-country heterogeneity. For this reason the purpose of this paper is to contribute to the literature by performing a fresh and comprehensive assessment of this hypothesis in a large cross-section of countries over a long sample.

\section{Data}

We use data for a total of 115 countries, both developed and developing countries over an extended period of time (1970-2013). The 115 countries are: Algeria, Argentina, Australia, Austria, Azerbaijan, Bahamas, Bahrain, Bangladesh, Barbados, Belarus, Belgium, Belize, Bhutan, Bolivia, Brazil, Bulgaria, Burundi, Cameroon, Canada, Central African Republic, Chile, China, Colombia, Congo Democratic Republic, Costa Rica, Cote d’Ivoire, Croatia, Cyprus, Czech Republic, Denmark, Dominican Republic, Ecuador, Egypt Arab Republic, El Salvador, Estonia, Ethiopia, Fiji, Finland, France, Gambia, Georgia, Germany, Ghana, Greece, Guatemala, Guinea, Honduras, Hong Kong SAR, Hungary, Iceland, India, Indonesia, Ireland, Israel, Italy, Jamaica, Japan, Jordan, Kazakhstan, Kenya, Korea Democratic Republic, Kyrgyz Republic, Latvia, Lesotho, Lithuania, Luxembourg, Malaysia, Maldives, Malta, Mauritius, Mexico, Moldova, Mongolia, Morocco, Myanmar, Nepal, Netherlands, New Zealand, Nicaragua, Nigeria, Norway, Oman, Pakistan, Panama, Paraguay, Peru, Philippines, Portugal, Romania, Russian Federation, San Marino, Senegal, Seychelles, Sierra Leone, Singapore, Slovak Republic, South Africa, Spain, Sri Lanka, St. Vincent and the Grenadines, Sweden,

\footnotetext{
2 These breakpoints are identified endogenously.
} 
Switzerland, Thailand, Trinidad and Tobago, Tunisia, Turkey, Uganda, Ukraine, United Kingdom, United States, Uruguay, Vanuatu, Venezuela, Zambia and Zimbabwe.

To assess real economic growth, we make use of the annual percentage change rate of the GDP at market prices expressed in constant US\$2005 taking from the World Bank National Accounts and OECD National Accounts data.

\section{Empirical Strategy and Results}

\section{IV.1 Empirical strategy}

Our approach is decidedly empirical, taking advantage of a broad dataset on public debt and economic growth. We form groups of countries at the end of each year based on total (domestic plus external) gross central government debt as a share of GDP taking from Reinhart and Rogoff (2011) and from Datastream.

In order to create our debt classification we adopt the following procedure. First, we calculate the percentiles 25, 50 and 75 for our distribution. Then we apply the following criteria: if the total gross central government debt is less or equal than percentile 25 we categorize this country as low debt group, if the total of indebtedness is between percentile 25 and percentile 50 will be considered as lower-middle debt group, if the central debt is between percentile 50 and percentile 75 is upper-middle debt group and finally if it exceeds percentile 75 we assign it on high debt group.

Starting in 1970, we recursively form groups of countries based on the debt classification and we track their growth performance. The dynamic rebalancing of country groups enables us to look at the average growth performance of groups of countries with similar level of indebtedness.

This procedure circumvents the need to assume a specific channel through which public debt might influence growth. Additionally, this approach produces results which are readily interpretable in terms of economic significance, since the difference in growth differentials between groups directly yields an estimate of how much higher the rate of growth is in countries with a given level of indebtedness versus countries with an alternative one. 


\section{IV.II Empirical results}

We considered four statistics to evaluate the economic growth performance of each group of countries: the mean, the median, the $20 \%$ trimmed mean and the $20 \%$ winsorized mean.

Table 1 (Panel A) presents the results. As can be seen, those countries that present the lowest public debt are characterized by the highest economic growth, while the smallest growth rates are associated with the highest public debt. In order to investigate the existence of means equality between different debt groups, first it has been implemented several variance equality test in which the null hypothesis contrast what is called homogeneity of variance (see for instance, Levene, Brown-Forsythe, Bartlett test, among others). Depending on whether we can reject or not the null hypothesis of variance equality, Table 1 presents the results of Welch F-test or ANOVA F-test, respectively. These formal tests of mean equality indicate that there are indeed significant differences between low and high debt groups in terms of economic growth. Regardless of the method used, those countries with the highest level of debt show almost one percent less in its economic growth rate. Additionally, our results also suggest significant differences between lower-middle and high debt countries and between upper-middle and high debt countries, but not between lower-middle and upper-middle countries.

To assess the robustness of our results, we divide economies under study in four income groups using the World Bank's classification: low income, lower middle income, upper middle income and high income. Given that income classifications are set each year based on their per capita income data, we recursively formed groups of countries based on the public debt and income classifications, tracking their growth performance. In this case, we need to clarify that we calculate different percentiles 25, 50 and 75 for each income countries groups in order to get a more accurate debt classification. Panels B to $\mathrm{E}$ in Table 1 report the results. It can be seen that low-income countries have a different behaviour with respect to lower-middle, upper-middle and high income countries. Except for the case of upper middle versus high debt, clearly we can reject the null hypothesis of formal mean equality tests regardless of whether we use mean, median, winsorized mean or trimmed mean. As the level of debt increases the economic growth experiences a progressively decrease. Comparing our four statistics we can say that the 
highest debt group is associated with the lowest economic growth (around 3\% of the GDP), while the upper-middle debt group almost reaches a $4 \%$. It is possible to obtain a higher level of output for lower-middle debt group and even higher for countries that try to avoid excessive budget deficits. Analyzing lower-middle-income countries, there are only significant statistical differences between low and high debt indicating that austerity policies suppose higher output. Nevertheless, for upper-middle-income and high-income countries it cannot be appreciated any differences in terms of growth studying different level of indebtedness.

Our results suggest that the level of debt accumulation specially matters for low and lower-middle-income countries due to the fact that higher levels of debt imply lower economic growth. For this reason, it must have a very strict control of indebtedness since there are significant differences between low and high debt groups. However, for upper-middle-income and high-income countries it seems that economic growth is not affected by the level of debt.

\section{IV.III Further empirical results}

In order to gain further insights into the relation between public debt and economic growth and to obtain additional evidence on the robustness of our results, we divide economies under study according to the International Monetary Fund (IMF)'s country classifications. As before, we recursively formed groups of countries based on the public debt and income classifications, tracking their growth performance.

Table 2 reports the results for the IMF's coarse classification: advanced countries, developing countries and countries in transition. Interestingly, for the advanced economies (Panel A in Table 2) there is not a significant different pattern in growth behaviour between the four groups of level of debt. Regarding the developing countries, results in Panel B of Table 2 suggest a negative and significant relationship between economic growth and the level of public debt. Finally, with respect to the countries in transition (Panel $\mathrm{C}$ in Table 2), we observe that, with the exception of the lower middle debt group, the higher the public debt, the lower the rate of economic growth. Nevertheless, the only statistical difference in performance between groups is that for upper-middle debt and high debt countries. 
In Table 3, we show the results for the IMF's fine classification: European Union countries, newly industrialized Asian countries, other advanced economies, Sub-Sahara countries, North Africa countries, Asian developing countries, Middle East and Europe countries, Western Hemisphere developing countries, Central and Eastern Europe countries and Transcaucasus and Central Asia countries. As can be seen in Panel A of Table 3, in the case of the European Union countries there is not a statistically significant difference in the relationship of public debt and economic growth between the four groups of level of debt. As for the newly industrialized Asian countries (Panel B in Table 3), the highest growth rates are associated with upper middle levels of public debt, being the difference with the low debt level statistically significant. Regarding, the other advanced economies (Panel $\mathrm{C}$ in Table 3), there are statistically significant differences in the growth performance between the low and lower middle debt levels, between the lower middle and high debt levels, and between the upper middle and high debt levels, being the highest growth rates associated with lower middle debt countries. Turning to the case of the developing countries, results in Panel D of Table 3 suggest that there is not any statistically significant pattern relating public debt and economic growth for the Sub-Sahara countries, while for the North Africa countries (Panel E in Table 3), we detect a statistically significant difference in the growth performance between the low and lower middle debt levels, presenting the latter higher growth rates. In respect to the Asian developing countries (Panel $F$ in Table 3), we do find statistically significant differences in growth rates between the debt groups, the highest growth rates being associated with the lowest debt countries. Regarding the Middle East and Europe countries (Panel G in Table 3), we observe a statistically significant difference in the growth behaviour between the low and high debt levels and between the lower middle and high debt levels, being the highest growth rates associated with high debt countries. In relation to the Western Hemisphere developing countries (Panel $\mathrm{H}$ in Table 3), we identify statistically significant differences in economic growth between the low and high debt levels, the lower middle and high debt levels and between upper middle and high debt, showing that the higher the public debt, the lower the economic growth rate. Finally, referring to countries in transition, neither for the Central and Eastern Europe countries (Panel I in Table 3) nor for the Transcaucasus and Central Asia countries (Panel J in Table 3) we find evidence of statistically significant differences in growth rates between the debt groups. 


\section{Concluding remarks}

This paper tried to contribute to the previous literature by providing a comprehensive characterization of the relation between public debt and economic growth and offering a guide to regulators and policy makers further empirical evidence to assess under what conditions is debt growth-enhancing. To that end, we empirically investigated the relation between public debt and economic growth using annual data for 115 economies covering the period 1970-2013, searching for a systemic relationship between these two variables.

Using the World Bank's classification for income groups, our results initially indicate that those countries that present the lowest public debt are characterized by the highest economic growth, while the smallest growth rates are associated with the highest public debt. This result is consistent with higher debt ratios being associated on average, with lower GDP growth rates (Reinhart and Rogoff, 2010). Nevertheless, this conclusion is tempered when we analyse the countries by income level: low-income countries have a different behaviour with respect to lower-middle, upper-middle and high income countries.

When using the IMF's country classification, the results do not suggest a clear pattern in the debt-growth nexus across different countries, but indicate a heterogeneous relationship between such key macroeconomic variables. Therefore, our results lend support to the view that debt overhang effects cannot be related to a specific debt threshold and that the relationship between public debt and growth is complex.

A natural extension to the analysis presented in this paper would be to explore the main determinants of the detected differences in the relationships between public debt and economic growth across countries, with special emphasis in the institutional factors as suggested by Hall and Jones (1999), Acemoglu (2009) and Acemoglu and Robinson (2012). This is an item in our future research agenda. 


\section{Acknowledgements}

The authors thank the insightful comments of two anonymous referees and the editor that have helped to substantially improve this paper. Simón Sosvilla-Rivero also thanks the hospitality provided by the Department of Economics during a research visit at the University of Bath. Responsibility for any remaining errors rests with the authors.

\section{Funding}

This work is supported by the Spanish Ministry of Education, Culture and Sport through the Subprograma Estatal de Movilidad, del Plan Estatal de Investigación Científica y Técnica y de Innovación 2013- 2016 under Grant PRX16/00261. 


\section{References:}

Abbas, S.M.A. and Christensen J.E. (2010). The role of domestic debt markets in economic growth: an empirical investigation for low-income countries and emerging markets, IMF Staff Papers, 57: 209-55.

Acemoglu, D. (2009). Introduction to Modern Economic Growth. Princeton: Princeton University Press.

Acemoglu, D. and J. Robinson (2012). Why Nations Fail. New York: Crown Publishing Group.

Aizenman, J., K. Kletzer and B. Pinto (2007) Economic growth with constraints on tax revenues and public debt: implications for fiscal policy and cross-country differences, Working Paper 12750, National Bureau of Economic Research, Cambridge, MA.

Alesina, A.; Ardagna, S. 2010. Large changes in fiscal policy: Taxes versus spending, in: Brown, J. R. (Ed.) Tax Policy and the Economy, Vol. 24. Chicago: University of Chicago Press (pp. 35-68).

Alesina, A., Barbiero, O., Favero, C., Giavazzi, F., Paradisi., M. (2015). Austerity in 2009-2013. Working Paper 20827, National Bureau of Economic Research, Cambridge, MA.

Aschauer, D. A. (2000) Do states optimize? Public capital and economic growth. The Annals of Regional Science, 34, 343-363.

Bal, D. P. and Rath, B. N. (2014) Public debt and economic growth in India: A reassessment. Economic Analysis and Policy, 44, 292-300.

Baldacci, E., and Kumar, M. (2010) Fiscal deficits, public debt and sovereign bond yields, Working Paper 10/184, International Monetary Fund, Washington, DC. 
Barro, R. J. (1979). On the determinants of the public debt, Journal of Political Economy, 85 , 940-971.

Barro, R. J. (1990). Government spending in a simple model of endogeneous growth. Journal of Political Economy, 98, 103-125.

Barro, R. J. (2013). Inflation and economic growth. Annals of Economics and Finance, $14,121-144$.

Baum, A.; Checherita-Westphal, C. and Rother, P. (2013) Debt and growth: New evidence for the Euro Area. Journal of International Money and Finance, 32, 809-821.

Caner, M., Grennes, T. and Koehler-Geib, F. (2010). Finding the tipping point-when sovereign debt turns bad, Policy Research Working Paper 5391, The World Bank, Washington, DC.

Cecchetti, S., Mohanty, M. and Zampolli, F. (2011) Achieving growth amid fiscal imbalances: The real effects of debt, Economic Symposium Conference Proceedings. Federal Reserve Bank of Kansas City (pp. 145-196).

Chudik, A., K. Mohaddes, M. H. Pesaran, and Raissi, M. (2013) Debt, inflation and growth: robust estimation of long-run effects in dynamic panel data models, Working Paper 4508, Center for Economic Studies and Ifo Institute, Munich.

Cochrane, J. (2011) Understanding policy in the great recession: Some unpleasant fiscal arithmetic. European Economic Review, 55, 2-30.

Cordella, T., Ricci, L.A. and Ruiz-Arranz, M. (2010) Debt overhang or debt irrelevance? IMF Staff Papers, 57, 1-24.

Delong, B. J. and Summers, L. H. (2012) Fiscal policy in a depressed economy, Brookings Papers on Economic Activity, Spring, 233-274. 
Diamond, P. (1965) National debt in a neoclassical growth model, American Economic Review, 55, 1126-1150.

Dotsey, M. (1994) Some unpleasant supply side arithmetic. Journal of Monetary Economics, 33, 507-524.

Égert, B. (2015) The 90\% public debt threshold: The rise and fall of a stylised fact. Applied Economics, 47, 3756-3770.

Elmendorf, D. and Mankiw, N. (1999) Government debt, in Taylor, J. and Woodford, M. (eds.), Handbook of Macroeconomics, Vol. 1C, Amsterdam: North-Holland (pp. 1615-1669).

Ferreira, C. (2009) Public debt and economic growth: A Granger causality panel data approach. Working Paper 24, Technical University of Lisbon, Lisbon.

Gale, W. and Orszag, P. (2003) The economic effects of long-term fiscal discipline. Discussion Paper 8, Urban-Brookings Tax Policy Center, Washington, DC.

Geiger L.T. (1990) Debt and economic development in Latin America. Journal of Developing Areas, 24, 181-194.

Gómez-Puig, M. and Sosvilla-Rivero, S. (2015) The causal relationship between public debt and economic growth in EMU countries, Journal of Policy Modeling, 37, 974-989.

Guajardo, J., Leigh, D. and Pescatori. A. (2014) Expansionary austerity: New international evidence. Journal of the European Economic Association, 12, 949-968.

Hall, R. E. and C. I. Jones (1999) Why do some countries produce so much more output per worker than others? Quarterly Journal of Economics, 114, 83-116.

Ismihan, M., Ozkan, F.G., (2012) Public debt and financial development: a theoretical exploration. Economics Letters, 115, 348-351. 
Kannan, R., Singh, B., 2007. Debt-deficit dynamics in India and macroeconomic effects: A structural approach. Munich Personal RePEc Archive 16480. Available on the web: http://mpra.ub.uni-muenchen.de/16480/.

Krugman, P. (2011) Self-defeating austerity, New York Times, July 7.

Kumar, M. S. and Woo, J. (2015) Public debt and growth. Economica, 82, 705-739.

Jordà, O. and Taylor, A.M. (2016) The time for austerity: Estimating the average treatment effect of fiscal policy. The Economic Journal 126, 219-255.

Minea, A. and Parent, A. (2012) Is high public debt always harmful to economic growth? Reinhart and Rogoff and some complex nonlinearities. Document de Travail E. 2012.18, Centre d'Etudes et de Recherche sur le Développement International, Clermont-Ferrand.

Modigliani, F. (1961) Long-run implications of alternative fiscal policies and the burden of the national debt, Economic Journal, 71, 730-755.

Newey, W. and West, K. (1987). A simple positive semi-definite, heteroskedasticity and autocorrelation consistent covariance matrix, Econometrica, 55: 703-708.

Panizza, H. and Presbitero, A. F. (2013) Public debt and economic growth in advanced economies: A survey. Swiss Journal of Economics and Statistics, 149, 175-204.

Panizza, H. and Presbitero, A. F. (2014) Public debt and economic growth: Is there a causal effect? Journal of Macroeconomics, 41, 21-41.

Pattillo, C. A., Poirson, H. and Ricci, L. A. (2011) External debt and growth. Review of Econiomics and Institutions, 2(3), Article 2

Presbitero, A. F. (2005) The debt-growth nexus: A dynamic panel data estimation, Quaderno Di Ricerca 243, Università Politecnica delle Marche, Ancona. 
Presbitero, A. F (2012) Total public debt and growth in developing countries. European Journal of Development Research, 24, 606-626.

Puente-Ajovín, M. and Sanso-Navarro, M. (2015) Granger causality between debt and growth: evidence from OECD countries. International Review of Economic and Finance, 35, 66-77

Qureshi, M. N. and Ali, K. (2010) Public debt burden and economic growth: Evidence from Pakistan. International Research Journal of Finance and Economics, 53, 100-108.

Rangarajan, C. and Srivastava, D.K. (2005) Fiscal deficits and government debt: implications for growth and stabilisation. Economic and Political Weekly, 40, 29192934.

Reinhart, C. M. and Rogoff, K. S. (2010) Growth in a time of debt. American Economic Review, 100, 573-578.

Reinhart, C. M. and Rogoff, K. S. (2011) From financial crash to debt crisis, American Economic Review, 101 1676-1706.

Salotti, S. and Trecoci, C. (2016) The impact of government debt, expenditure and taxes on aggregate investment and productivity growth. Economica, 83, 356-384.

Sargent, T., and Wallace, N. (1981) Some unpleasant monetarist arithmetic. Federal Reserve Bank of Minneapolis Quarterly Review, 5, 1-17.

Schclarek, A. (2005) Debt and economic growth in developing industrial countries. Working Paper 34. Lund University, Lund. 
Table 1: Empirical results using the World Bank's classification

\begin{tabular}{|c|c|c|c|c|}
\hline & Mean & Median & $\begin{array}{c}\text { Winsorised } \\
\text { mean }\end{array}$ & $\begin{array}{c}\text { Trimmed } \\
\text { mean }\end{array}$ \\
\hline \multicolumn{5}{|l|}{ Panel A: All countries } \\
\hline Low debt & $\begin{array}{c}4.0617 \\
(15.9072)\end{array}$ & $\begin{array}{c}3.9340 \\
(16.7370)\end{array}$ & $\begin{array}{c}4.0040 \\
(16.1417)\end{array}$ & $\begin{array}{c}3.9684 \\
(16.4490)\end{array}$ \\
\hline Lower middle debt & $\begin{array}{c}3.7831 \\
(12.7679)\end{array}$ & $\begin{array}{c}3.9852 \\
(13.8740)\end{array}$ & $\begin{array}{c}3.9337 \\
(14.7046)\end{array}$ & $\begin{array}{c}3.9384 \\
(14.4672)\end{array}$ \\
\hline Upper middle debt & $\begin{array}{c}3.6669 \\
(15.0041)\end{array}$ & $\begin{array}{c}3.6103 \\
(17.7815)\end{array}$ & $\begin{array}{c}3.6700 \\
(17.8155)\end{array}$ & $\begin{array}{c}3.6842 \\
(18.6549)\end{array}$ \\
\hline High debt & $\begin{array}{c}2.8717 \\
(9.2848)\end{array}$ & $\begin{array}{c}3.0970 \\
(10.0438)\end{array}$ & $\begin{array}{c}3.0387 \\
(10.9862)\end{array}$ & $\begin{array}{c}3.0623 \\
(10.7929)\end{array}$ \\
\hline $\begin{array}{l}\text { Low vs Lower middle } \\
\text { debt }\end{array}$ & $\begin{array}{c}0.5072 \\
{[0.4783]}\end{array}$ & $\begin{array}{c}0.0190 \\
{[0.8906]}\end{array}$ & $\begin{array}{c}0.0371 \\
{[0.8477]}\end{array}$ & $\begin{array}{c}0.0068 \\
{[0.9345]}\end{array}$ \\
\hline $\begin{array}{l}\text { Low vs Upper middle } \\
\text { debt }\end{array}$ & $\begin{array}{c}1.2478 \\
{[0.2672]}\end{array}$ & $\begin{array}{c}1.0859 \\
{[0.3004]}\end{array}$ & $\begin{array}{c}1.0727 \\
{[0.3033]}\end{array}$ & $\begin{array}{c}0.8311 \\
{[0.3646]}\end{array}$ \\
\hline Low vs High debt & $\begin{array}{l}8.8030 * \\
{[0.0039]}\end{array}$ & $\begin{array}{l}4.6605 * * \\
{[0.0337]}\end{array}$ & $\begin{array}{c}6.7504^{*} \\
{[0.0111]}\end{array}$ & $\begin{array}{l}5.9189 * * \\
{[0.0171]}\end{array}$ \\
\hline $\begin{array}{l}\text { Lower middle vs } \\
\text { Upper middle debt }\end{array}$ & $\begin{array}{c}0.0916 \\
{[0.7629]}\end{array}$ & $\begin{array}{c}1.1356 \\
{[0.2896]}\end{array}$ & $\begin{array}{c}0.6099 \\
{[0.4370]}\end{array}$ & $\begin{array}{c}0.5714 \\
{[0.4518]}\end{array}$ \\
\hline $\begin{array}{l}\text { Lower middle vs High } \\
\text { debt }\end{array}$ & $\begin{array}{l}4.5278 * * \\
{[0.0363]}\end{array}$ & $\begin{array}{l}4.4423 * * \\
{[0.0380]}\end{array}$ & $\begin{array}{l}5.4102 * * \\
{[0.0224]}\end{array}$ & $\begin{array}{l}4.9642 * * \\
{[0.0285]}\end{array}$ \\
\hline $\begin{array}{l}\text { Upper middle vs High } \\
\text { debt }\end{array}$ & $\begin{array}{l}4.0690 * * \\
{[0.0469]}\end{array}$ & $\begin{array}{c}1.9334 \\
{[0.1686]}\end{array}$ & $\begin{array}{c}3.3511 * * * \\
{[0.0710]}\end{array}$ & $\begin{array}{c}3.2359 * * * \\
{[0.0761]}\end{array}$ \\
\hline
\end{tabular}


Table 1 (continued)

\begin{tabular}{|c|c|c|c|c|}
\hline & Mean & Median & $\begin{array}{c}\text { Winsorised } \\
\text { mean }\end{array}$ & $\begin{array}{c}\text { Trimmed } \\
\text { mean }\end{array}$ \\
\hline \multicolumn{5}{|c|}{ Panel B: Low-income countries } \\
\hline Low debt & $\begin{array}{c}6.2576 \\
(10.3822)\end{array}$ & $\begin{array}{c}6.3390 \\
(10.4411)\end{array}$ & $\begin{array}{c}6.3487 \\
(10.4939)\end{array}$ & $\begin{array}{c}6.3471 \\
(10.4871)\end{array}$ \\
\hline Lower middle debt & $\begin{array}{c}5.0251 \\
(10.6811)\end{array}$ & $\begin{array}{c}4.9141 \\
(14.1079)\end{array}$ & $\begin{array}{c}4.9509 \\
(13.7923)\end{array}$ & $\begin{array}{c}4.9463 \\
(13.9260)\end{array}$ \\
\hline Upper middle debt & $\begin{array}{c}3.3178 \\
(7.8511)\end{array}$ & $\begin{array}{c}3.8450 \\
(9.9427)\end{array}$ & $\begin{array}{c}3.7390 \\
(9.3380)\end{array}$ & $\begin{array}{c}3.7572 \\
(9.4617)\end{array}$ \\
\hline High debt & $\begin{array}{c}2.6122 \\
(5.6908)\end{array}$ & $\begin{array}{c}3.1638 \\
(7.4990)\end{array}$ & $\begin{array}{c}2.9775 \\
(6.5574)\end{array}$ & $\begin{array}{c}3.0113 \\
(7.1739)\end{array}$ \\
\hline $\begin{array}{l}\text { Low vs Lower middle } \\
\text { debt }\end{array}$ & $\begin{array}{c}2.5819 \\
{[0.1121]}\end{array}$ & $\begin{array}{l}4.1447 * * \\
{[0.0465]}\end{array}$ & $\begin{array}{l}3.9485 * * \\
{[0.0511]}\end{array}$ & $\begin{array}{l}3.9845 * * \\
{[0.0501]}\end{array}$ \\
\hline $\begin{array}{l}\text { Low vs Upper middle } \\
\text { debt }\end{array}$ & $\begin{array}{l}15.9494^{*} \\
{[0.0001]}\end{array}$ & $\begin{array}{l}12.0050 * \\
{[0.0009]}\end{array}$ & $\begin{array}{l}12.9397^{*} \\
{[0.0006]}\end{array}$ & $\begin{array}{l}12.8012 * \\
{[0.0006]}\end{array}$ \\
\hline Low vs High debt & $\begin{array}{c}23.4250 * \\
{[0.0000]}\end{array}$ & $\begin{array}{l}18.7384 * \\
{[0.0000]}\end{array}$ & $\begin{array}{c}21.2355^{*} \\
{[0.0000]}\end{array}$ & $\begin{array}{l}20.8397 * \\
{[0.0000]}\end{array}$ \\
\hline $\begin{array}{l}\text { Lower middle vs } \\
\text { Upper middle debt }\end{array}$ & $\begin{array}{l}7.3058^{*} \\
{[0.0084]}\end{array}$ & $\begin{array}{l}4.2071 * * \\
{[0.0436]}\end{array}$ & $\begin{array}{c}5.0634^{* *} \\
{[0.0272]}\end{array}$ & $\begin{array}{c}4.9665^{* *} \\
{[0.0287]}\end{array}$ \\
\hline $\begin{array}{l}\text { Lower middle vs High } \\
\text { debt }\end{array}$ & $\begin{array}{l}13.4638^{*} \\
{[0.0004]}\end{array}$ & $\begin{array}{l}10.0675 * \\
{[0.0021]}\end{array}$ & $\begin{array}{l}12.5258 * \\
{[0.0007]}\end{array}$ & $\begin{array}{l}12.2034^{*} \\
{[0.0008]}\end{array}$ \\
\hline $\begin{array}{l}\text { Upper middle vs High } \\
\text { debt }\end{array}$ & $\begin{array}{c}1.2723 \\
{[0.2626]}\end{array}$ & $\begin{array}{c}1.4089 \\
{[0.2387]}\end{array}$ & $\begin{array}{c}1.7142 \\
{[0.1941]}\end{array}$ & $\begin{array}{c}1.6599 \\
{[0.2012]}\end{array}$ \\
\hline
\end{tabular}


Table 1 (continued)

\begin{tabular}{|c|c|c|c|c|}
\hline & Mean & Median & $\begin{array}{c}\text { Winsorised } \\
\text { mean }\end{array}$ & $\begin{array}{c}\text { Trimmed } \\
\text { mean }\end{array}$ \\
\hline \multicolumn{5}{|c|}{ Panel C: Lower-middle-income countries } \\
\hline Low debt & $\begin{array}{c}4.4990 \\
(11.8179)\end{array}$ & $\begin{array}{c}4.8496 \\
(14.0197)\end{array}$ & $\begin{array}{c}4.5375 \\
(12.3577)\end{array}$ & $\begin{array}{c}4.5948 \\
(12.9212)\end{array}$ \\
\hline Lower middle debt & $\begin{array}{c}4.1543 \\
(9.6880)\end{array}$ & $\begin{array}{c}4.2840 \\
(11.0099)\end{array}$ & $\begin{array}{c}4.3496 \\
(11.2192)\end{array}$ & $\begin{array}{c}4.3477 \\
(11.3688)\end{array}$ \\
\hline Upper middle debt & $\begin{array}{c}4.0078 \\
(13.0037)\end{array}$ & $\begin{array}{c}3.9830 \\
(14.4720)\end{array}$ & $\begin{array}{c}3.9924 \\
(14.2144)\end{array}$ & $\begin{array}{c}4.0131 \\
(14.6345)\end{array}$ \\
\hline High debt & $\begin{array}{c}3.3051 \\
(7.7630)\end{array}$ & $\begin{array}{c}3.6240 \\
(10.9768)\end{array}$ & $\begin{array}{c}3.3843 \\
(9.3771)\end{array}$ & $\begin{array}{c}3.4387 \\
(9.7707)\end{array}$ \\
\hline $\begin{array}{l}\text { Low vs Lower middle } \\
\text { debt }\end{array}$ & $\begin{array}{c}0.3604 \\
{[0.5499]}\end{array}$ & $\begin{array}{c}1.1764 \\
{[0.2812]}\end{array}$ & $\begin{array}{c}0.1235 \\
{[0.7261]}\end{array}$ & $\begin{array}{c}0.2235 \\
{[0.6376]}\end{array}$ \\
\hline $\begin{array}{l}\text { Low vs Upper middle } \\
\text { debt }\end{array}$ & $\begin{array}{c}1.0103 \\
{[0.3178]}\end{array}$ & $\begin{array}{l}3.8627 * * \\
{[0.0527]}\end{array}$ & $\begin{array}{c}1.3983 \\
{[0.2404]}\end{array}$ & $\begin{array}{c}1.6876 \\
{[0.1975]}\end{array}$ \\
\hline Low vs High debt & $\begin{array}{c}4.3572^{* *} \\
{[0.0399]}\end{array}$ & $\begin{array}{c}6.5750 * \\
{[0.0121]}\end{array}$ & $\begin{array}{c}4.9901 * * \\
{[0.0282]}\end{array}$ & $\begin{array}{l}5.3392 * * \\
{[0.0233]}\end{array}$ \\
\hline $\begin{array}{l}\text { Lower middle vs } \\
\text { Upper middle debt }\end{array}$ & $\begin{array}{c}0.0769 \\
{[0.7823]}\end{array}$ & $\begin{array}{c}0.3989 \\
{[0.5294]}\end{array}$ & $\begin{array}{c}0.5567 \\
{[0.4579]}\end{array}$ & $\begin{array}{c}0.5054 \\
{[0.4793]}\end{array}$ \\
\hline $\begin{array}{l}\text { Lower middle vs High } \\
\text { debt }\end{array}$ & $\begin{array}{c}1.9753 \\
{[0.1636]}\end{array}$ & $\begin{array}{c}1.6732 \\
{[0.1994]}\end{array}$ & $\begin{array}{c}3.3048 * * * \\
{[0.0726]}\end{array}$ & $\begin{array}{c}3.0587 * * * \\
{[0.0840]}\end{array}$ \\
\hline $\begin{array}{l}\text { Upper middle vs High } \\
\text { debt }\end{array}$ & $\begin{array}{c}1.7877 \\
{[0.1852]}\end{array}$ & $\begin{array}{c}0.6978 \\
{[0.4059]}\end{array}$ & $\begin{array}{c}1.7564 \\
{[0.1887]}\end{array}$ & $\begin{array}{c}1.6575 \\
{[0.2015]}\end{array}$ \\
\hline
\end{tabular}


Table 1 (continued)

\begin{tabular}{|c|c|c|c|c|}
\hline & Mean & Median & $\begin{array}{c}\text { Winsorised } \\
\text { mean }\end{array}$ & $\begin{array}{c}\text { Trimmed } \\
\text { mean }\end{array}$ \\
\hline \multicolumn{5}{|c|}{ Panel D: Upper-middle-income countries } \\
\hline Low debt & $\begin{array}{c}3.3495 \\
(8.8814)\end{array}$ & $\begin{array}{c}3.4235 \\
(8.8633)\end{array}$ & $\begin{array}{c}3.4260 \\
(8.7585)\end{array}$ & $\begin{array}{c}3.4266 \\
(8.7801)\end{array}$ \\
\hline Lower middle debt & $\begin{array}{c}3.5622 \\
(6.7276)\end{array}$ & $\begin{array}{c}3.6840 \\
(7.3535)\end{array}$ & $\begin{array}{c}3.6656 \\
(7.3170)\end{array}$ & $\begin{array}{c}3.6691 \\
(7.3328)\end{array}$ \\
\hline Upper middle debt & $\begin{array}{c}4.0046 \\
(7.6995)\end{array}$ & $\begin{array}{c}4.0141 \\
(7.7654)\end{array}$ & $\begin{array}{c}4.0371 \\
(7.7877)\end{array}$ & $\begin{array}{c}4.0348 \\
(7.7975)\end{array}$ \\
\hline High debt & $\begin{array}{c}3.3774 \\
(5.7529)\end{array}$ & $\begin{array}{c}3.3504 \\
(5.7303)\end{array}$ & $\begin{array}{c}3.3679 \\
(5.7387)\end{array}$ & $\begin{array}{c}3.3651 \\
(5.7385)\end{array}$ \\
\hline $\begin{array}{l}\text { Low vs Lower middle } \\
\text { debt }\end{array}$ & $\begin{array}{c}0.1079 \\
{[0.7434]}\end{array}$ & $\begin{array}{c}0.1705 \\
{[0.6807]}\end{array}$ & $\begin{array}{c}0.1428 \\
{[0.7064]}\end{array}$ & $\begin{array}{c}0.1469 \\
{[0.7025]}\end{array}$ \\
\hline $\begin{array}{l}\text { Low vs Upper middle } \\
\text { debt }\end{array}$ & $\begin{array}{c}1.0397 \\
{[0.3108]}\end{array}$ & $\begin{array}{c}0.8374 \\
{[0.3628]}\end{array}$ & $\begin{array}{c}0.8854 \\
{[0.3494]}\end{array}$ & $\begin{array}{c}0.8807 \\
{[0.3507]}\end{array}$ \\
\hline Low vs High debt & $\begin{array}{c}0.0016 \\
{[0.9682]}\end{array}$ & $\begin{array}{c}0.01088 \\
{[0.9172]}\end{array}$ & $\begin{array}{c}0.0068 \\
{[0.9345]}\end{array}$ & $\begin{array}{c}0.0076 \\
{[0.9307]}\end{array}$ \\
\hline $\begin{array}{l}\text { Lower middle vs } \\
\text { Upper middle debt }\end{array}$ & $\begin{array}{c}0.3553 \\
{[0.5527]}\end{array}$ & $\begin{array}{c}0.2100 \\
{[0.6480]}\end{array}$ & $\begin{array}{c}0.2653 \\
{[0.6079]}\end{array}$ & $\begin{array}{c}0.2578 \\
{[0.6130]}\end{array}$ \\
\hline $\begin{array}{l}\text { Lower middle vs High } \\
\text { debt }\end{array}$ & $\begin{array}{c}0.0545 \\
{[0.8160]}\end{array}$ & $\begin{array}{c}0.1870 \\
{[0.6666]}\end{array}$ & $\begin{array}{c}0.1483 \\
{[0.7012]}\end{array}$ & $\begin{array}{c}0.1549 \\
{[0.6949]}\end{array}$ \\
\hline $\begin{array}{l}\text { Upper middle vs High } \\
\text { debt }\end{array}$ & $\begin{array}{c}0.6394 \\
{[0.4262]}\end{array}$ & $\begin{array}{c}0.7231 \\
{[0.3976]}\end{array}$ & $\begin{array}{c}0.7305 \\
{[0.3952]}\end{array}$ & $\begin{array}{c}0.7332 \\
{[0.3943]}\end{array}$ \\
\hline
\end{tabular}


Table 1 (continued)

\begin{tabular}{|c|c|c|c|c|}
\hline & Mean & Median & $\begin{array}{c}\text { Winsorised } \\
\text { mean }\end{array}$ & $\begin{array}{c}\text { Trimmed } \\
\text { mean }\end{array}$ \\
\hline \multicolumn{5}{|c|}{ Panel E: High-income countries } \\
\hline Low debt & $\begin{array}{c}2.8562 \\
(12.1182)\end{array}$ & $\begin{array}{c}2.7196 \\
(11.9641)\end{array}$ & $\begin{array}{c}2.7343 \\
(12.5503)\end{array}$ & $\begin{array}{c}2.7333 \\
(12.5634)\end{array}$ \\
\hline Lower middle debt & $\begin{array}{c}3.0625 \\
(7.5634)\end{array}$ & $\begin{array}{c}2.9433 \\
(8.3672)\end{array}$ & $\begin{array}{c}3.0962 \\
(8.4797)\end{array}$ & $\begin{array}{c}3.0599 \\
(8.4628)\end{array}$ \\
\hline Upper middle debt & $\begin{array}{c}3.0457 \\
(9.6128)\end{array}$ & $\begin{array}{c}2.8831 \\
(10.8494)\end{array}$ & $\begin{array}{c}2.8902 \\
(10.5921)\end{array}$ & $\begin{array}{c}2.8879 \\
(10.6575)\end{array}$ \\
\hline High debt & $\begin{array}{c}3.5444 \\
(8.5501)\end{array}$ & $\begin{array}{c}3.0287 \\
(7.4922)\end{array}$ & $\begin{array}{c}3.1855 \\
(7.8805)\end{array}$ & $\begin{array}{c}.1533 \\
(7.8365)\end{array}$ \\
\hline $\begin{array}{l}\text { Low vs Lower middle } \\
\text { debt }\end{array}$ & $\begin{array}{c}0.1939 \\
{[0.6611]}\end{array}$ & $\begin{array}{c}0.2853 \\
{[0.5946]}\end{array}$ & $\begin{array}{c}0.7242 \\
{[0.3972]}\end{array}$ & $\begin{array}{c}0.5988 \\
{[0.4412]}\end{array}$ \\
\hline $\begin{array}{l}\text { Low vs Upper middle } \\
\text { debt }\end{array}$ & $\begin{array}{c}0.2303 \\
{[0.6325]}\end{array}$ & $\begin{array}{c}0.2187 \\
{[0.6412]}\end{array}$ & $\begin{array}{c}0.1992 \\
{[0.6565]}\end{array}$ & $\begin{array}{c}0.1978 \\
{[0.6577]}\end{array}$ \\
\hline Low vs High debt & $\begin{array}{c}2.0832 \\
{[0.1536]}\end{array}$ & $\begin{array}{c}0.4444 \\
{[0.5069]}\end{array}$ & $\begin{array}{c}0.9651 \\
{[0.3296]}\end{array}$ & $\begin{array}{c}0.8428 \\
{[0.3620]}\end{array}$ \\
\hline $\begin{array}{l}\text { Lower middle vs } \\
\text { Upper middle debt }\end{array}$ & $\begin{array}{c}0.0011 \\
{[0.9740]}\end{array}$ & $\begin{array}{c}0.0186 \\
{[0.8917]}\end{array}$ & $\begin{array}{c}0.2042 \\
{[0.6525]}\end{array}$ & $\begin{array}{c}0.1449 \\
{[0.7044]}\end{array}$ \\
\hline $\begin{array}{l}\text { Lower middle vs High } \\
\text { debt }\end{array}$ & $\begin{array}{c}0.6918 \\
{[0.4079]}\end{array}$ & $\begin{array}{c}0.0254 \\
{[0.8737]}\end{array}$ & $\begin{array}{c}0.0269 \\
{[0.8702]}\end{array}$ & $\begin{array}{c}0.0298 \\
{[0.8633]}\end{array}$ \\
\hline $\begin{array}{l}\text { Upper middle vs High } \\
\text { debt }\end{array}$ & $\begin{array}{c}0.9138 \\
{[0.3418]}\end{array}$ & $\begin{array}{c}0.0906 \\
{[0.7642]}\end{array}$ & $\begin{array}{c}0.3666 \\
{[0.5465]}\end{array}$ & $\begin{array}{c}0.2993 \\
{[0.5858]}\end{array}$ \\
\hline
\end{tabular}

Notes:

In the ordinary brackets below the parameter estimates are the corresponding $t$-statistics based on Newey and West (1987) standard errors.

$\mathrm{XX} v$ s. XX are equality tests. In the square brackets we report the associated $p$-values are given. ${ }^{*}, * *$ and $* * *$ indicate significance at $1 \%, 5 \%$, and $10 \%$ respectively. 
Table 2: Empirical results combining the World Bank's classification with the IMF's coarse classification

\begin{tabular}{|c|c|c|c|c|}
\hline & Mean & Median & $\begin{array}{c}\text { Winsorised } \\
\text { mean }\end{array}$ & $\begin{array}{c}\text { Trimmed } \\
\text { mean }\end{array}$ \\
\hline \multicolumn{5}{|c|}{ Panel A: Advanced countries } \\
\hline Low debt & $\begin{array}{c}2.8702 \\
(10.7602)\end{array}$ & $\begin{array}{c}2.8111 \\
(11.2200)\end{array}$ & $\begin{array}{c}2.8014 \\
(10.8577)\end{array}$ & $\begin{array}{c}2.8050 \\
(10.9160)\end{array}$ \\
\hline Lower middle debt & $\begin{array}{c}3.2607 \\
(7.7230) \\
\end{array}$ & $\begin{array}{c}3.0749 \\
(8.5569) \\
\end{array}$ & $\begin{array}{c}3.1985 \\
(8.4961) \\
\end{array}$ & $\begin{array}{c}3.1725 \\
(8.5540) \\
\end{array}$ \\
\hline Upper middle debt & $\begin{array}{c}3.1266 \\
(9.4734)\end{array}$ & $\begin{array}{c}3.0011 \\
(10.8134)\end{array}$ & $\begin{array}{c}2.9781 \\
(9.7400)\end{array}$ & $\begin{array}{c}2.9844 \\
(9.9896)\end{array}$ \\
\hline High debt & $\begin{array}{c}3.4355 \\
(10.0170)\end{array}$ & $\begin{array}{c}3.0056 \\
(10.0166)\end{array}$ & $\begin{array}{c}3.0633 \\
(9.8967) \\
\end{array}$ & $\begin{array}{c}3.0515 \\
(9.9530)\end{array}$ \\
\hline $\begin{array}{l}\text { Low vs Lower middle } \\
\text { debt }\end{array}$ & $\begin{array}{c}0.6116 \\
{[0.4368]}\end{array}$ & $\begin{array}{c}0.3655 \\
{[0.5471]}\end{array}$ & $\begin{array}{c}0.7630 \\
{[0.3849]}\end{array}$ & $\begin{array}{c}0.6688 \\
{[0.4158]}\end{array}$ \\
\hline $\begin{array}{l}\text { Low vs Upper middle } \\
\text { debt }\end{array}$ & $\begin{array}{c}0.3668 \\
{[0.5463]}\end{array}$ & $\begin{array}{c}0.2589 \\
{[0.6122]}\end{array}$ & $\begin{array}{c}0.1957 \\
{[0.6594]}\end{array}$ & $\begin{array}{c}0.2080 \\
{[0.6495]}\end{array}$ \\
\hline Low vs High debt & $\begin{array}{c}1.7111 \\
{[0.1944]}\end{array}$ & $\begin{array}{c}0.2495 \\
{[0.6188]}\end{array}$ & $\begin{array}{c}0.4255 \\
{[0.5160]}\end{array}$ & $\begin{array}{c}0.3825 \\
{[0.5379]}\end{array}$ \\
\hline $\begin{array}{l}\text { Lower middle vs } \\
\text { Upper middle debt }\end{array}$ & $\begin{array}{c}0.0626 \\
{[0.8030]}\end{array}$ & $\begin{array}{c}0.0264 \\
{[0.8713]}\end{array}$ & $\begin{array}{c}0.2065 \\
{[0.6507]}\end{array}$ & $\begin{array}{c}0.1560 \\
{[0.6939]}\end{array}$ \\
\hline $\begin{array}{l}\text { Lower middle vs High } \\
\text { debt }\end{array}$ & $\begin{array}{c}0.1027 \\
{[0.7488]}\end{array}$ & $\begin{array}{c}0.0218 \\
{[0.8830]}\end{array}$ & $\begin{array}{c}0.0765 \\
{[0.7827]}\end{array}$ & $\begin{array}{c}0.0629 \\
{[0.8026]}\end{array}$ \\
\hline $\begin{array}{l}\text { Upper middle vs High } \\
\text { debt }\end{array}$ & $\begin{array}{c}0.4215 \\
{[0.5180]}\end{array}$ & $\begin{array}{c}0.0001 \\
{[0.9912]}\end{array}$ & $\begin{array}{c}0.0384 \\
{[0.8452]}\end{array}$ & $\begin{array}{c}0.0246 \\
{[0.8758]}\end{array}$ \\
\hline
\end{tabular}


Table 2 (continued)

\begin{tabular}{|c|c|c|c|c|}
\hline & Mean & Median & $\begin{array}{c}\text { Winsorised } \\
\text { mean }\end{array}$ & $\begin{array}{c}\text { Trimmed } \\
\text { mean }\end{array}$ \\
\hline \multicolumn{5}{|c|}{ Panel B: Developing countries } \\
\hline Low debt & $\begin{array}{c}4.6551 \\
(18.0374)\end{array}$ & $\begin{array}{c}4.6614 \\
(16.3237)\end{array}$ & $\begin{array}{c}4.6068 \\
(17.3746)\end{array}$ & $\begin{array}{c}4.6181 \\
(17.3359)\end{array}$ \\
\hline Lower middle debt & $\begin{array}{c}4.1270 \\
(12.3375)\end{array}$ & $\begin{array}{c}4.4003 \\
(15.9249)\end{array}$ & $\begin{array}{c}4.2491 \\
(14.5449)\end{array}$ & $\begin{array}{c}4.2931 \\
(14.9516)\end{array}$ \\
\hline Upper middle debt & $\begin{array}{c}3.7266 \\
(16.7390)\end{array}$ & $\begin{array}{c}4.1295 \\
(20.3492)\end{array}$ & $\begin{array}{c}3.9579 \\
(20.4368)\end{array}$ & $\begin{array}{c}4.0231 \\
(21.3339)\end{array}$ \\
\hline High debt & $\begin{array}{c}3.3153 \\
(9.5707)\end{array}$ & $\begin{array}{c}3.5916 \\
(12.2024)\end{array}$ & $\begin{array}{c}3.6310 \\
(12.6316)\end{array}$ & $\begin{array}{c}3.6214 \\
(12.6342)\end{array}$ \\
\hline $\begin{array}{l}\text { Low vs Lower middle } \\
\text { debt }\end{array}$ & $\begin{array}{c}1.5622 \\
{[0.2151]}\end{array}$ & $\begin{array}{c}0.4323 \\
{[0.5127]}\end{array}$ & $\begin{array}{c}0.8202 \\
{[0.3677]}\end{array}$ & $\begin{array}{c}0.6869 \\
{[0.4096]}\end{array}$ \\
\hline $\begin{array}{l}\text { Low vs Upper middle } \\
\text { debt }\end{array}$ & $\begin{array}{l}\text { 7.4214* } \\
{[0.0079]}\end{array}$ & $\begin{array}{c}2.3057 \\
{[0.1327]}\end{array}$ & $\begin{array}{l}3.9060 * * \\
{[0.0515]}\end{array}$ & $\begin{array}{c}3.3235 * * * \\
{[0.0719]}\end{array}$ \\
\hline Low vs High debt & $\begin{array}{l}9.6191 * \\
{[0.0027]}\end{array}$ & $\begin{array}{c}6.7987^{*} \\
{[0.0108]}\end{array}$ & $\begin{array}{l}6.2134^{*} \\
{[0.0147]}\end{array}$ & $\begin{array}{c}6.4748^{*} \\
{[0.0128]}\end{array}$ \\
\hline $\begin{array}{l}\text { Lower middle vs } \\
\text { Upper middle debt }\end{array}$ & $\begin{array}{c}0.9932 \\
{[0.3223]}\end{array}$ & $\begin{array}{c}0.6192 \\
{[0.4336]}\end{array}$ & $\begin{array}{c}0.6901 \\
{[0.4089]}\end{array}$ & $\begin{array}{c}0.6180 \\
{[0.4344]}\end{array}$ \\
\hline $\begin{array}{l}\text { Lower middle vs High } \\
\text { debt }\end{array}$ & $\begin{array}{c}2.8411^{* * *} \\
{[0.0956]}\end{array}$ & $\begin{array}{l}4.0122 * * \\
{[0.0484]}\end{array}$ & $\begin{array}{c}2.2745 \\
{[0.1353]}\end{array}$ & $\begin{array}{c}2.7415 * * * \\
{[0.1015]}\end{array}$ \\
\hline $\begin{array}{l}\text { Upper middle vs High } \\
\text { debt }\end{array}$ & $\begin{array}{c}0.9974 \\
{[0.3213]}\end{array}$ & $\begin{array}{c}2.2636 \\
{[0.1367]}\end{array}$ & $\begin{array}{c}0.8817 \\
{[0.3505]}\end{array}$ & $\begin{array}{c}1.3708 \\
{[0.2455]}\end{array}$ \\
\hline
\end{tabular}


Table 2 (continued)

\begin{tabular}{|c|c|c|c|c|}
\hline & Mean & Median & $\begin{array}{c}\text { Winsorised } \\
\text { mean }\end{array}$ & $\begin{array}{c}\text { Trimmed } \\
\text { mean }\end{array}$ \\
\hline \multicolumn{5}{|c|}{ Panel C: Countries in transition } \\
\hline Low debt & $\begin{array}{c}3.4221 \\
(3.1473)\end{array}$ & $\begin{array}{c}3.4922 \\
(3.1198)\end{array}$ & $\begin{array}{c}3.4923 \\
(3.1202)\end{array}$ & $\begin{array}{c}3.4907 \\
(3.1201)\end{array}$ \\
\hline Lower middle debt & $\begin{array}{c}1.8120 \\
(1.6134)\end{array}$ & $\begin{array}{c}2.0248 \\
(1.9689)\end{array}$ & $\begin{array}{c}1.9526 \\
(1.8964)\end{array}$ & $\begin{array}{c}1.9647 \\
(1.9093)\end{array}$ \\
\hline Upper middle debt & $\begin{array}{c}4.2015 \\
(3.0205)\end{array}$ & $\begin{array}{c}4.0230 \\
(2.7665)\end{array}$ & $\begin{array}{c}4.0230 \\
(2.7665)\end{array}$ & $\begin{array}{c}4.0230 \\
(2.7665)\end{array}$ \\
\hline High debt & $\begin{array}{c}0.8985 \\
(1.0117)\end{array}$ & $\begin{array}{c}1.2785 \\
(1.4858)\end{array}$ & $\begin{array}{c}1.2785 \\
(1.4858)\end{array}$ & $\begin{array}{c}1.2785 \\
(1.4858)\end{array}$ \\
\hline $\begin{array}{l}\text { Low vs Lower middle } \\
\text { debt }\end{array}$ & $\begin{array}{c}1.0590 \\
{[0.3096]}\end{array}$ & $\begin{array}{c}0.9191 \\
{[0.3438]}\end{array}$ & $\begin{array}{c}1.0111 \\
{[0.3210]}\end{array}$ & $\begin{array}{c}0.9942 \\
{[0.3250]}\end{array}$ \\
\hline $\begin{array}{l}\text { Low vs Upper middle } \\
\text { debt }\end{array}$ & $\begin{array}{c}0.2002 \\
{[0.6574]}\end{array}$ & $\begin{array}{c}0.0864 \\
{[0.7706]}\end{array}$ & $\begin{array}{c}0.0863 \\
{[0.7707]}\end{array}$ & $\begin{array}{c}0.0869 \\
{[0.7699]}\end{array}$ \\
\hline Low vs High debt & $\begin{array}{c}3.2584 * * * \\
{[0.0784]}\end{array}$ & $\begin{array}{c}2.4862 \\
{[0.1225]}\end{array}$ & $\begin{array}{c}2.4868 \\
{[0.1225]}\end{array}$ & $\begin{array}{c}2.4844 \\
{[0.1227]}\end{array}$ \\
\hline $\begin{array}{l}\text { Lower middle vs } \\
\text { Upper middle debt }\end{array}$ & $\begin{array}{c}1.8283 \\
{[0.1858]}\end{array}$ & $\begin{array}{c}1.3291 \\
{[0.2575]}\end{array}$ & $\begin{array}{c}1.4253 \\
{[0.2413]}\end{array}$ & $\begin{array}{c}1.4096 \\
{[0.2439]}\end{array}$ \\
\hline $\begin{array}{l}\text { Lower middle vs } \\
\text { High debt }\end{array}$ & $\begin{array}{c}0.4169 \\
{[0.5223]}\end{array}$ & $\begin{array}{c}0.3147 \\
{[0.5780]}\end{array}$ & $\begin{array}{c}0.2565 \\
{[0.6154]}\end{array}$ & $\begin{array}{c}0.2659 \\
{[0.6090]}\end{array}$ \\
\hline $\begin{array}{l}\text { Upper middle vs High } \\
\text { debt }\end{array}$ & $\begin{array}{c}4.4185^{* *} \\
{[0.0428]}\end{array}$ & $\begin{array}{c}2.9910 * * * \\
{[0.0925]}\end{array}$ & $\begin{array}{c}2.9910 * * * \\
{[0.0925]}\end{array}$ & $\begin{array}{c}2.9910 * * * \\
{[0.0925]}\end{array}$ \\
\hline
\end{tabular}

Notes:

In the ordinary brackets below the parameter estimates are the corresponding $t$-statistics based on Newey and West (1987) standard errors.

$\mathrm{XX} v$ s. XX are equality tests. In the square brackets we report the associated $p$-values are given. ${ }^{*}, * *$ and $* * *$ indicate significance at $1 \%, 5 \%$, and $10 \%$ respectively. 
Table 3: Empirical results combining the World Bank's classification with the IMF's fine classification

\begin{tabular}{|c|c|c|c|c|}
\hline & Mean & Median & $\begin{array}{c}\text { Winsorised } \\
\text { mean }\end{array}$ & $\begin{array}{c}\text { Trimmed } \\
\text { mean }\end{array}$ \\
\hline \multicolumn{5}{|c|}{ Panel A: European Union countries } \\
\hline Low debt & $\begin{array}{c}3.0814 \\
(7.4421)\end{array}$ & $\begin{array}{c}3.0932 \\
(8.2429)\end{array}$ & $\begin{array}{c}3.1235 \\
(8.3579)\end{array}$ & $\begin{array}{c}3.1184 \\
(8.3442)\end{array}$ \\
\hline Lower middle debt & $\begin{array}{c}3.0988 \\
(6.9873)\end{array}$ & $\begin{array}{c}3.0282 \\
(8.3508)\end{array}$ & $\begin{array}{c}3.0672 \\
(8.2148)\end{array}$ & $\begin{array}{c}3.0559 \\
(8.2576)\end{array}$ \\
\hline Upper middle debt & $\begin{array}{c}2.7619 \\
(5.2629) \\
\end{array}$ & $\begin{array}{c}2.5456 \\
(4.9914) \\
\end{array}$ & $\begin{array}{c}2.5334 \\
(4.9228) \\
\end{array}$ & $\begin{array}{c}2.5349 \\
(4.9361) \\
\end{array}$ \\
\hline High debt & $\begin{array}{c}2.9603 \\
(7.5733)\end{array}$ & $\begin{array}{c}2.6033 \\
(7.7654)\end{array}$ & $\begin{array}{c}2.6181 \\
(7.8256)\end{array}$ & $\begin{array}{c}2.6157 \\
(7.8166)\end{array}$ \\
\hline $\begin{array}{l}\text { Low vs Lower middle } \\
\text { debt }\end{array}$ & $\begin{array}{c}0.0008 \\
{[0.9771]}\end{array}$ & $\begin{array}{c}0.0155 \\
{[0.9013]}\end{array}$ & $\begin{array}{c}0.0114 \\
{[0.9154]}\end{array}$ & $\begin{array}{c}0.0141 \\
{[0.9056]}\end{array}$ \\
\hline $\begin{array}{l}\text { Low vs Upper middle } \\
\text { debt }\end{array}$ & $\begin{array}{c}0.2285 \\
{[0.6340]}\end{array}$ & $\begin{array}{c}0.7510 \\
{[0.3890]}\end{array}$ & $\begin{array}{c}0.8608 \\
{[0.3565]}\end{array}$ & $\begin{array}{c}0.8441 \\
{[0.3612]}\end{array}$ \\
\hline Low vs High debt & $\begin{array}{c}0.0452 \\
{[0.8322]}\end{array}$ & $\begin{array}{c}0.9479 \\
{[0.3331]}\end{array}$ & $\begin{array}{c}1.0151 \\
{[0.3167]}\end{array}$ & $\begin{array}{c}1.0045 \\
{[0.3192]}\end{array}$ \\
\hline $\begin{array}{l}\text { Lower middle vs } \\
\text { Upper middle debt }\end{array}$ & $\begin{array}{c}0.2405 \\
{[0.6252]}\end{array}$ & $\begin{array}{c}0.5976 \\
{[0.4420]}\end{array}$ & $\begin{array}{c}0.7048 \\
{[0.4039]}\end{array}$ & $\begin{array}{c}0.6774 \\
{[0.4131]}\end{array}$ \\
\hline $\begin{array}{l}\text { Lower middle vs High } \\
\text { debt }\end{array}$ & $\begin{array}{c}0.0549 \\
{[0.8153]}\end{array}$ & $\begin{array}{c}0.7405 \\
{[0.3920]}\end{array}$ & $\begin{array}{c}0.8024 \\
{[0.3730]}\end{array}$ & $\begin{array}{c}0.7785 \\
{[0.3802]}\end{array}$ \\
\hline $\begin{array}{l}\text { Upper middle vs High } \\
\text { debt }\end{array}$ & $\begin{array}{c}0.0920 \\
{[0.7625]}\end{array}$ & $\begin{array}{c}0.0092 \\
{[0.9236]}\end{array}$ & $\begin{array}{c}0.0190 \\
{[0.8906]}\end{array}$ & $\begin{array}{c}0.0174 \\
{[0.8955]}\end{array}$ \\
\hline
\end{tabular}


Table 3 (continued)

\begin{tabular}{|c|c|c|c|c|}
\hline & Mean & Median & $\begin{array}{c}\text { Winsorised } \\
\text { mean }\end{array}$ & $\begin{array}{c}\text { Trimmed } \\
\text { mean }\end{array}$ \\
\hline \multicolumn{5}{|c|}{ Panel B: Newly Industrialized Asian countries } \\
\hline Low debt & $\begin{array}{c}2.7385 \\
(1.1874)\end{array}$ & $\begin{array}{c}2.7385 \\
(1.1874)\end{array}$ & $\begin{array}{c}2.7385 \\
(1.1874)\end{array}$ & $\begin{array}{c}2.7385 \\
(1.1874)\end{array}$ \\
\hline Lower middle debt & $\begin{array}{c}5.7534 \\
(4.7029)\end{array}$ & $\begin{array}{c}5.7534 \\
(4.7029)\end{array}$ & $\begin{array}{c}5.7534 \\
(4.7029)\end{array}$ & $\begin{array}{c}5.7534 \\
(4.7029)\end{array}$ \\
\hline Upper middle debt & $\begin{array}{c}8.7281 \\
(6.7907)\end{array}$ & $\begin{array}{c}8.7281 \\
(6.7907)\end{array}$ & $\begin{array}{c}8.7281 \\
(6.7907)\end{array}$ & $\begin{array}{c}8.7281 \\
(6.7907)\end{array}$ \\
\hline High debt & $\begin{array}{c}6.9251 \\
(9.4516)\end{array}$ & $\begin{array}{c}6.9251 \\
(9.4516)\end{array}$ & $\begin{array}{c}6.9251 \\
(9.4516)\end{array}$ & $\begin{array}{c}6.9251 \\
(9.4516)\end{array}$ \\
\hline $\begin{array}{l}\text { Low vs Lower middle } \\
\text { debt }\end{array}$ & $\begin{array}{c}1.3337 \\
{[0.3050]}\end{array}$ & $\begin{array}{c}1.3337 \\
{[0.3050]}\end{array}$ & $\begin{array}{c}1.3337 \\
{[0.3050]}\end{array}$ & $\begin{array}{c}1.3337 \\
{[0.3050]}\end{array}$ \\
\hline $\begin{array}{l}\text { Low vs Upper middle } \\
\text { debt }\end{array}$ & $\begin{array}{c}5.1463 * * * \\
{[0.0725]}\end{array}$ & $\begin{array}{c}5.1463 * * * \\
{[0.0725]}\end{array}$ & $\begin{array}{c}5.1463 * * * \\
{[0.0725]}\end{array}$ & $\begin{array}{c}5.1463 * * * \\
{[0.0725]}\end{array}$ \\
\hline Low vs High debt & $\begin{array}{c}2.9933 \\
{[0.1659]}\end{array}$ & $\begin{array}{c}2.9933 \\
{[0.1659]}\end{array}$ & $\begin{array}{c}2.9933 \\
{[0.1659]}\end{array}$ & $\begin{array}{c}2.9933 \\
{[0.1659]}\end{array}$ \\
\hline $\begin{array}{l}\text { Lower middle vs } \\
\text { Upper middle debt }\end{array}$ & $\begin{array}{c}2.8103 \\
{[0.1255]}\end{array}$ & $\begin{array}{c}2.8103 \\
{[0.1255]}\end{array}$ & $\begin{array}{c}2.8103 \\
{[0.1255]}\end{array}$ & $\begin{array}{c}2.8103 \\
{[0.1255]}\end{array}$ \\
\hline $\begin{array}{l}\text { Lower middle vs } \\
\text { High debt }\end{array}$ & $\begin{array}{c}0.6752 \\
{[0.4456]}\end{array}$ & $\begin{array}{c}0.6752 \\
{[0.4456]}\end{array}$ & $\begin{array}{c}0.6752 \\
{[0.4456]}\end{array}$ & $\begin{array}{c}0.6752 \\
{[0.4456]}\end{array}$ \\
\hline $\begin{array}{l}\text { Upper middle vs High } \\
\text { debt }\end{array}$ & $\begin{array}{c}1.4851 \\
{[0.2397]}\end{array}$ & $\begin{array}{c}1.4851 \\
{[0.2397]}\end{array}$ & $\begin{array}{c}1.4851 \\
{[0.2397]}\end{array}$ & $\begin{array}{c}1.4851 \\
{[0.2397]}\end{array}$ \\
\hline
\end{tabular}


Table 3 (continued)

\begin{tabular}{|c|c|c|c|c|}
\hline & Mean & Median & $\begin{array}{c}\text { Winsorised } \\
\text { mean }\end{array}$ & $\begin{array}{c}\text { Trimmed } \\
\text { mean }\end{array}$ \\
\hline \multicolumn{5}{|c|}{ Panel C: Other advanced economies } \\
\hline Low debt & $\begin{array}{c}2.5783 \\
(10.3996)\end{array}$ & $\begin{array}{c}2.6217 \\
(9.5068)\end{array}$ & $\begin{array}{c}2.6197 \\
(9.5038)\end{array}$ & $\begin{array}{c}2.6200 \\
(9.5044)\end{array}$ \\
\hline Lower middle debt & $\begin{array}{c}3.8007 \\
(8.0137)\end{array}$ & $\begin{array}{c}3.8228 \\
(8.0416)\end{array}$ & $\begin{array}{c}3.8228 \\
(8.0416)\end{array}$ & $\begin{array}{c}3.8228 \\
(8.0416)\end{array}$ \\
\hline Upper middle debt & $\begin{array}{c}3.0945 \\
(12.5858)\end{array}$ & $\begin{array}{c}3.1264 \\
(12.3097)\end{array}$ & $\begin{array}{c}3.1264 \\
(12.3097)\end{array}$ & $\begin{array}{c}3.1264 \\
(12.3097)\end{array}$ \\
\hline High debt & $\begin{array}{c}2.2310 \\
(5.6944)\end{array}$ & $\begin{array}{c}2.1835 \\
(5.0153)\end{array}$ & $\begin{array}{c}2.1835 \\
(5.0153)\end{array}$ & $\begin{array}{c}2.1835 \\
(5.0153)\end{array}$ \\
\hline $\begin{array}{l}\text { Low vs Lower middle } \\
\text { debt }\end{array}$ & $\begin{array}{l}4.8727^{* *} \\
{[0.0306]}\end{array}$ & $\begin{array}{l}4.4963 * * \\
{[0.0375]}\end{array}$ & $\begin{array}{l}4.5116^{* *} \\
{[0.0372]}\end{array}$ & $\begin{array}{c}4.5091 * * \\
{[0.0373]}\end{array}$ \\
\hline $\begin{array}{l}\text { Low vs Upper middle } \\
\text { debt }\end{array}$ & $\begin{array}{c}2.1852 \\
{[0.1437]}\end{array}$ & $\begin{array}{c}1.8128 \\
{[0.1825]}\end{array}$ & $\begin{array}{c}1.8276 \\
{[0.1807]}\end{array}$ & $\begin{array}{c}1.8552 \\
{[0.1810]}\end{array}$ \\
\hline Low vs High debt & $\begin{array}{c}0.5681 \\
{[0.4537]}\end{array}$ & $\begin{array}{c}0.7318 \\
{[0.3954]}\end{array}$ & $\begin{array}{c}0.7255 \\
{[0.3975]}\end{array}$ & $\begin{array}{c}0.7266 \\
{[0.3971]}\end{array}$ \\
\hline $\begin{array}{l}\text { Lower middle vs } \\
\text { Upper middle debt }\end{array}$ & $\begin{array}{c}1.8233 \\
{[0.1809]}\end{array}$ & $\begin{array}{c}1.7387 \\
{[0.1912]}\end{array}$ & $\begin{array}{c}1.7387 \\
{[0.1912]}\end{array}$ & $\begin{array}{c}1.7387 \\
{[0.1912]}\end{array}$ \\
\hline $\begin{array}{l}\text { Lower middle vs } \\
\text { High debt }\end{array}$ & $\begin{array}{l}6.5109 * * \\
{[0.0130]}\end{array}$ & $\begin{array}{c}6.4667 * * \\
{[0.0132]}\end{array}$ & $\begin{array}{l}6.4667 * * \\
{[0.0132]}\end{array}$ & $\begin{array}{c}6.4667 * * \\
{[0.0132]}\end{array}$ \\
\hline $\begin{array}{l}\text { Upper middle vs High } \\
\text { debt }\end{array}$ & $\begin{array}{c}3.7566 * * * \\
{[0.0565]}\end{array}$ & $\begin{array}{c}3.8251^{* * *} \\
{[0.0544]}\end{array}$ & $\begin{array}{c}3.8251 * * * \\
{[0.0544]}\end{array}$ & $\begin{array}{c}3.8251^{* * *} \\
{[0.0544]}\end{array}$ \\
\hline
\end{tabular}


Table 3 (continued)

\begin{tabular}{|c|c|c|c|c|}
\hline & Mean & Median & $\begin{array}{c}\text { Winsorised } \\
\text { mean }\end{array}$ & $\begin{array}{c}\text { Trimmed } \\
\text { mean }\end{array}$ \\
\hline \multicolumn{5}{|c|}{ Panel D: Sub-Sahara countries } \\
\hline Low debt & $\begin{array}{c}3.7538 \\
(4.2876)\end{array}$ & $\begin{array}{c}3.8775 \\
(4.3587)\end{array}$ & $\begin{array}{c}3.7538 \\
(4.2876)\end{array}$ & $\begin{array}{c}3.7538 \\
(4.2876)\end{array}$ \\
\hline Lower middle debt & $\begin{array}{c}3.7092 \\
(5.0903)\end{array}$ & $\begin{array}{c}3.6940 \\
(5.5945)\end{array}$ & $\begin{array}{c}3.6874 \\
(5.5771)\end{array}$ & $\begin{array}{c}3.6890 \\
(5.5816)\end{array}$ \\
\hline Upper middle debt & $\begin{array}{c}2.8099 \\
(6.6820)\end{array}$ & $\begin{array}{c}3.2769 \\
(8.3498) \\
\end{array}$ & $\begin{array}{c}3.1417 \\
(7.5963) \\
\end{array}$ & $\begin{array}{c}3.1596 \\
(7.6927) \\
\end{array}$ \\
\hline High debt & $\begin{array}{c}2.2108 \\
(4.0800)\end{array}$ & $\begin{array}{c}2.7079 \\
(5.2240)\end{array}$ & $\begin{array}{c}2.6612 \\
(5.1964)\end{array}$ & $\begin{array}{c}2.6730 \\
(5.2167)\end{array}$ \\
\hline $\begin{array}{l}\text { Low vs Lower middle } \\
\text { debt }\end{array}$ & $\begin{array}{c}0.0015 \\
{[0.9688]}\end{array}$ & $\begin{array}{c}0.0272 \\
{[0.8694]}\end{array}$ & $\begin{array}{c}0.0036 \\
{[0.9521]}\end{array}$ & $\begin{array}{c}0.0035 \\
{[0.9533]}\end{array}$ \\
\hline $\begin{array}{l}\text { Low vs Upper middle } \\
\text { debt }\end{array}$ & $\begin{array}{c}0.9904 \\
{[0.3228]}\end{array}$ & $\begin{array}{c}0.4017 \\
{[0.5281]}\end{array}$ & $\begin{array}{c}0.4194 \\
{[0.5192]}\end{array}$ & $\begin{array}{c}0.3964 \\
{[0.5309]}\end{array}$ \\
\hline Low vs High debt & $\begin{array}{c}2.3810 \\
{[0.1269]}\end{array}$ & $\begin{array}{c}1.3786 \\
{[0.2439]}\end{array}$ & $\begin{array}{c}1.2391 \\
{[0.2691]}\end{array}$ & $\begin{array}{c}1.2119 \\
{[0.2743]}\end{array}$ \\
\hline $\begin{array}{l}\text { Lower middle vs } \\
\text { Upper middle debt }\end{array}$ & $\begin{array}{c}1.2000 \\
{[0.2769]}\end{array}$ & $\begin{array}{c}0.3089 \\
{[0.5800]}\end{array}$ & $\begin{array}{c}0.5106 \\
{[0.4771]}\end{array}$ & $\begin{array}{c}0.4831 \\
{[0.4892]}\end{array}$ \\
\hline $\begin{array}{l}\text { Lower middle vs High } \\
\text { debt }\end{array}$ & $\begin{array}{c}2.7229 \\
{[0.1036]}\end{array}$ & $\begin{array}{c}1.3800 \\
{[0.2441]}\end{array}$ & $\begin{array}{c}1.5512 \\
{[0.2167]}\end{array}$ & $\begin{array}{c}1.4761 \\
{[0.2285]}\end{array}$ \\
\hline $\begin{array}{l}\text { Upper middle vs High } \\
\text { debt }\end{array}$ & $\begin{array}{c}0.7630 \\
{[0.3851]}\end{array}$ & $\begin{array}{c}0.7488 \\
{[0.3894]}\end{array}$ & $\begin{array}{c}0.5235 \\
{[0.4714]}\end{array}$ & $\begin{array}{c}0.5490 \\
{[0.4609]}\end{array}$ \\
\hline
\end{tabular}


Table 3 (continued)

\begin{tabular}{|c|c|c|c|c|}
\hline & Mean & Median & $\begin{array}{c}\text { Winsorised } \\
\text { mean }\end{array}$ & $\begin{array}{c}\text { Trimmed } \\
\text { mean }\end{array}$ \\
\hline \multicolumn{5}{|c|}{ Panel E: North Africa countries } \\
\hline Low debt & $\begin{array}{c}3.0334 \\
(4.5096)\end{array}$ & $\begin{array}{c}3.0334 \\
(4.5096)\end{array}$ & $\begin{array}{c}3.0334 \\
(4.5096)\end{array}$ & $\begin{array}{c}3.0334 \\
(4.5096)\end{array}$ \\
\hline Lower middle debt & $\begin{array}{c}5.5785 \\
(6.2961)\end{array}$ & $\begin{array}{c}5.5785 \\
(6.2961)\end{array}$ & $\begin{array}{c}5.5785 \\
(6.2961)\end{array}$ & $\begin{array}{c}5.5785 \\
(6.2961)\end{array}$ \\
\hline Upper middle debt & $\begin{array}{c}4.1497 \\
(10.2398)\end{array}$ & $\begin{array}{c}4.1497 \\
(10.2398)\end{array}$ & $\begin{array}{c}4.1497 \\
(10.2398)\end{array}$ & $\begin{array}{c}4.1497 \\
(10.2398)\end{array}$ \\
\hline High debt & $\begin{array}{c}4.1641 \\
(5.2790)\end{array}$ & $\begin{array}{c}4.1438 \\
(5.2643)\end{array}$ & $\begin{array}{c}4.1438 \\
(5.3643)\end{array}$ & $\begin{array}{c}4.1438 \\
(5.3643)\end{array}$ \\
\hline $\begin{array}{l}\text { Low vs Lower middle } \\
\text { debt }\end{array}$ & $\begin{array}{l}5.2346 * * \\
{[0.0413]}\end{array}$ & $\begin{array}{l}5.2346 * * \\
{[0.0413]}\end{array}$ & $\begin{array}{c}5.2346 * * \\
{[0.0413]}\end{array}$ & $\begin{array}{l}5.2346 * * \\
{[0.0413]}\end{array}$ \\
\hline $\begin{array}{l}\text { Low vs Upper middle } \\
\text { debt }\end{array}$ & $\begin{array}{c}2.0210 \\
{[0.1885]}\end{array}$ & $\begin{array}{c}2.0210 \\
{[0.1885]}\end{array}$ & $\begin{array}{c}2.0210 \\
{[0.1885]}\end{array}$ & $\begin{array}{c}2.0210 \\
{[0.1885]}\end{array}$ \\
\hline Low vs High debt & $\begin{array}{c}0.3582 \\
{[0.5532]}\end{array}$ & $\begin{array}{c}0.3468 \\
{[0.5595]}\end{array}$ & $\begin{array}{c}0.3468 \\
{[0.5595]}\end{array}$ & $\begin{array}{c}0.3468 \\
{[0.5595]}\end{array}$ \\
\hline $\begin{array}{l}\text { Lower middle vs } \\
\text { Upper middle debt }\end{array}$ & $\begin{array}{c}2.1505 \\
{[0.1728]}\end{array}$ & $\begin{array}{c}2.1505 \\
{[0.1728]}\end{array}$ & $\begin{array}{c}2.1505 \\
{[0.1728]}\end{array}$ & $\begin{array}{c}2.1505 \\
{[0.1728]}\end{array}$ \\
\hline $\begin{array}{l}\text { Lower middle vs High } \\
\text { debt }\end{array}$ & $\begin{array}{c}1.4216 \\
{[0.2473]}\end{array}$ & $\begin{array}{c}1.4655 \\
{[0.2404]}\end{array}$ & $\begin{array}{c}1.4655 \\
{[0.2404]}\end{array}$ & $\begin{array}{c}1.4655 \\
{[0.2404]}\end{array}$ \\
\hline $\begin{array}{l}\text { Upper middle vs High } \\
\text { debt }\end{array}$ & $\begin{array}{c}0.0003 \\
{[0.9871]}\end{array}$ & $\begin{array}{l}4.58 \mathrm{E}-05 \\
{[0.9946]}\end{array}$ & $\begin{array}{c}4.58 \mathrm{E}-05 \\
{[0.9946]}\end{array}$ & $\begin{array}{l}4.58 E-05 \\
{[0.9946]}\end{array}$ \\
\hline
\end{tabular}


Table 3 (continued)

\begin{tabular}{|c|c|c|c|c|}
\hline & Mean & Median & $\begin{array}{c}\text { Winsorised } \\
\text { mean }\end{array}$ & $\begin{array}{c}\text { Trimmed } \\
\text { mean }\end{array}$ \\
\hline \multicolumn{5}{|c|}{ Panel F: Asian developing countries } \\
\hline Low debt & $\begin{array}{c}7.5282 \\
(17.6950)\end{array}$ & $\begin{array}{c}7.5145 \\
(18.2266)\end{array}$ & $\begin{array}{c}7.5166 \\
(18.3722)\end{array}$ & $\begin{array}{c}7.5171 \\
(18.3679)\end{array}$ \\
\hline Lower middle debt & $\begin{array}{c}5.3228 \\
(14.7722)\end{array}$ & $\begin{array}{c}5.5518 \\
(16.8010)\end{array}$ & $\begin{array}{c}5.5647 \\
(16.9130)\end{array}$ & $\begin{array}{c}5.5626 \\
(16.8960)\end{array}$ \\
\hline Upper middle debt & $\begin{array}{c}5.6689 \\
(12.8615)\end{array}$ & $\begin{array}{c}5.8066 \\
(13.5856)\end{array}$ & $\begin{array}{c}5.8066 \\
(13.5856)\end{array}$ & $\begin{array}{c}5.8066 \\
(13.5856)\end{array}$ \\
\hline High debt & $\begin{array}{c}4.8964 \\
(10.7893)\end{array}$ & $\begin{array}{c}4.8149 \\
(11.2819)\end{array}$ & $\begin{array}{c}4.8149 \\
(11.2819)\end{array}$ & $\begin{array}{c}4.8149 \\
(11.2819)\end{array}$ \\
\hline $\begin{array}{l}\text { Low vs Lower middle } \\
\text { debt }\end{array}$ & $\begin{array}{l}15.6463 * \\
{[0.0002]}\end{array}$ & $\begin{array}{l}13.7993 * \\
{[0.0004]}\end{array}$ & $\begin{array}{l}13.8218 * \\
{[0.0004]}\end{array}$ & $\begin{array}{l}13.8474 * \\
{[0.0004]}\end{array}$ \\
\hline $\begin{array}{l}\text { Low vs Upper middle } \\
\text { debt }\end{array}$ & $\begin{array}{l}9.2111^{*} \\
{[0.0034]}\end{array}$ & $\begin{array}{l}8.2710 * \\
{[0.0053]}\end{array}$ & $\begin{array}{l}8.3530 * \\
{[0.0051]}\end{array}$ & $\begin{array}{l}8.3552 * \\
{[0.0051]}\end{array}$ \\
\hline Low vs High debt & $\begin{array}{l}17.8992 * \\
{[0.0001]}\end{array}$ & $\begin{array}{l}20.6968 * \\
{[0.0000]}\end{array}$ & $\begin{array}{l}20.8831 * \\
{[0.0000]}\end{array}$ & $\begin{array}{c}20.8844^{*} \\
{[0.0000]}\end{array}$ \\
\hline $\begin{array}{l}\text { Lower middle vs } \\
\text { Upper middle debt }\end{array}$ & $\begin{array}{c}0.3696 \\
{[0.5452]}\end{array}$ & $\begin{array}{c}0.2226 \\
{[0.6386]}\end{array}$ & $\begin{array}{c}0.2011 \\
{[0.6553]}\end{array}$ & $\begin{array}{c}0.2046 \\
{[0.6525]}\end{array}$ \\
\hline $\begin{array}{l}\text { Lower middle vs } \\
\text { High debt }\end{array}$ & $\begin{array}{c}0.5416 \\
{[0.4644]}\end{array}$ & $\begin{array}{c}1.8636 \\
{[0.1769]}\end{array}$ & $\begin{array}{c}1.9361 \\
{[0.1688]}\end{array}$ & $\begin{array}{c}1.9241 \\
{[0.1702]}\end{array}$ \\
\hline $\begin{array}{l}\text { Upper middle vs High } \\
\text { debt }\end{array}$ & $\begin{array}{c}1.4912 \\
{[0.2263]}\end{array}$ & $\begin{array}{c}2.6958^{* * *} \\
{[0.1053]}\end{array}$ & $\begin{array}{c}2.6958 * * * \\
{[0.1053]}\end{array}$ & $\begin{array}{c}2.6958 * * * \\
{[0.1053]}\end{array}$ \\
\hline
\end{tabular}


Table 3 (continued)

\begin{tabular}{|c|c|c|c|c|}
\hline & Mean & Median & $\begin{array}{c}\text { Winsorised } \\
\text { mean }\end{array}$ & $\begin{array}{c}\text { Trimmed } \\
\text { mean }\end{array}$ \\
\hline \multicolumn{5}{|c|}{ Panel G: Middle East and Europe countries } \\
\hline Low debt & $\begin{array}{c}3.4442 \\
(6.1006)\end{array}$ & $\begin{array}{c}3.4442 \\
(6.1006)\end{array}$ & $\begin{array}{c}3.4442 \\
(6.1006)\end{array}$ & $\begin{array}{c}3.4442 \\
(6.1006)\end{array}$ \\
\hline Lower middle debt & $\begin{array}{c}4.4007 \\
(5.3629)\end{array}$ & $\begin{array}{c}4.4007 \\
(5.3629)\end{array}$ & $\begin{array}{c}4.4007 \\
(5.3629)\end{array}$ & $\begin{array}{c}4.4007 \\
(5.3629)\end{array}$ \\
\hline Upper middle debt & $\begin{array}{c}4.4576 \\
(5.2989)\end{array}$ & $\begin{array}{c}4.4576 \\
(5.2989) \\
\end{array}$ & $\begin{array}{c}4.4576 \\
(5.2989) \\
\end{array}$ & $\begin{array}{c}.4576 \\
(5.2989)\end{array}$ \\
\hline High debt & $\begin{array}{c}6.1253 \\
(8.5602)\end{array}$ & $\begin{array}{c}6.2254 \\
(8.6686)\end{array}$ & $\begin{array}{c}6.2254 \\
(8.6686)\end{array}$ & $\begin{array}{c}6.2254 \\
(8.6686)\end{array}$ \\
\hline $\begin{array}{l}\text { Low vs Lower middle } \\
\text { debt }\end{array}$ & $\begin{array}{c}0.9221 \\
{[0.3448]}\end{array}$ & $\begin{array}{c}0.9221 \\
{[0.3448]}\end{array}$ & $\begin{array}{c}0.9221 \\
{[0.3448]}\end{array}$ & $\begin{array}{c}0.9221 \\
{[0.3448]}\end{array}$ \\
\hline $\begin{array}{l}\text { Low vs Upper middle } \\
\text { debt }\end{array}$ & $\begin{array}{c}1.0006 \\
{[0.3256]}\end{array}$ & $\begin{array}{c}1.0006 \\
{[0.3256]}\end{array}$ & $\begin{array}{c}1.0006 \\
{[0.3256]}\end{array}$ & $\begin{array}{c}1.0006 \\
{[0.3256]}\end{array}$ \\
\hline Low vs High debt & $\begin{array}{l}8.6528 * \\
{[0.0048]}\end{array}$ & $\begin{array}{l}9.2694^{*} \\
{[0.0036]}\end{array}$ & $\begin{array}{l}9.2694^{*} \\
{[0.0036]}\end{array}$ & $\begin{array}{c}9.2694^{*} \\
{[0.0036]}\end{array}$ \\
\hline $\begin{array}{l}\text { Lower middle vs } \\
\text { Upper middle debt }\end{array}$ & $\begin{array}{c}0.0023 \\
{[0.9617]}\end{array}$ & $\begin{array}{c}0.0023 \\
{[0.9617]}\end{array}$ & $\begin{array}{c}0.0023 \\
{[0.9617]}\end{array}$ & $\begin{array}{c}0.0023 \\
{[0.9617]}\end{array}$ \\
\hline $\begin{array}{l}\text { Lower middle vs } \\
\text { High debt }\end{array}$ & $\begin{array}{c}2.5092 \\
{[0.1221]}\end{array}$ & $\begin{array}{c}2.8002 * * * \\
{[0.1030]}\end{array}$ & $\begin{array}{c}2.8002 * * * \\
{[0.1030]}\end{array}$ & $\begin{array}{c}2.8002^{* * *} \\
{[0.1030]}\end{array}$ \\
\hline $\begin{array}{l}\text { Upper middle vs High } \\
\text { debt }\end{array}$ & $\begin{array}{c}2.2802 \\
{[0.1401]}\end{array}$ & $\begin{array}{c}2.5543 \\
{[0.1190]}\end{array}$ & $\begin{array}{c}2.5543 \\
{[0.1190]}\end{array}$ & $\begin{array}{c}2.5543 \\
{[0.1190]}\end{array}$ \\
\hline
\end{tabular}


Table 3 (continued)

\begin{tabular}{|c|c|c|c|c|}
\hline & Mean & Median & $\begin{array}{c}\text { Winsorised } \\
\text { mean }\end{array}$ & $\begin{array}{c}\text { Trimmed } \\
\text { mean }\end{array}$ \\
\hline \multicolumn{5}{|c|}{ Panel H: Western Hemisphere developing countries } \\
\hline Low debt & $\begin{array}{c}3.7863 \\
(10.3439)\end{array}$ & $\begin{array}{c}3.7843 \\
(11.2856)\end{array}$ & $\begin{array}{c}3.7874 \\
(11.6109)\end{array}$ & $\begin{array}{c}3.7859 \\
(11.6206)\end{array}$ \\
\hline Lower middle debt & $\begin{array}{c}3.6064 \\
(7.5951)\end{array}$ & $\begin{array}{c}3.7555 \\
(8.6108)\end{array}$ & $\begin{array}{c}3.6670 \\
(8.5084)\end{array}$ & $\begin{array}{c}3.6700 \\
(8.5339)\end{array}$ \\
\hline Upper middle debt & $\begin{array}{c}3.6074 \\
(9.5715)\end{array}$ & $\begin{array}{c}3.6619 \\
(9.8949)\end{array}$ & $\begin{array}{c}3.5923 \\
(9.7333)\end{array}$ & $\begin{array}{c}3.6039 \\
(9.8684)\end{array}$ \\
\hline High debt & $\begin{array}{c}2.6413 \\
(4.8979)\end{array}$ & $\begin{array}{c}2.5796 \\
(5.1594)\end{array}$ & $\begin{array}{c}2.5542 \\
(5.0335)\end{array}$ & $\begin{array}{c}2.5652 \\
(5.0850)\end{array}$ \\
\hline $\begin{array}{l}\text { Low vs Lower middle } \\
\text { debt }\end{array}$ & $\begin{array}{c}0.0888 \\
{[0.7665]}\end{array}$ & $\begin{array}{c}0.0027 \\
{[0.9587]}\end{array}$ & $\begin{array}{c}0.0489 \\
{[0.8256]}\end{array}$ & $\begin{array}{c}0.0455 \\
{[0.8316]}\end{array}$ \\
\hline $\begin{array}{l}\text { Low vs Upper middle } \\
\text { debt }\end{array}$ & $\begin{array}{c}0.1159 \\
{[0.7344]}\end{array}$ & $\begin{array}{c}0.0601 \\
{[0.8070]}\end{array}$ & $\begin{array}{c}0.1570 \\
{[0.6930]}\end{array}$ & $\begin{array}{c}0.1383 \\
{[0.7110]}\end{array}$ \\
\hline Low vs High debt & $\begin{array}{c}3.0862 * * * \\
{[0.0832]}\end{array}$ & $\begin{array}{c}3.9663 * * \\
{[0.0498]}\end{array}$ & $\begin{array}{c}4.1789 * * \\
{[0.0447]} \\
\end{array}$ & $\begin{array}{l}4.1318 * * \\
{[0.0459]}\end{array}$ \\
\hline $\begin{array}{l}\text { Lower middle vs } \\
\text { Upper middle debt }\end{array}$ & $\begin{array}{l}2.6 \mathrm{E}-06 \\
{[0.9987]}\end{array}$ & $\begin{array}{c}0.0268 \\
{[0.8704]}\end{array}$ & $\begin{array}{c}0.0174 \\
{[0.8955]}\end{array}$ & $\begin{array}{c}0.0137 \\
{[0.9070]}\end{array}$ \\
\hline $\begin{array}{l}\text { Lower middle vs } \\
\text { High debt }\end{array}$ & $\begin{array}{c}1.8042 \\
{[0.1829]}\end{array}$ & $\begin{array}{c}3.1411 * * * \\
{[0.0801]}\end{array}$ & $\begin{array}{c}2.7938 * * * \\
{[0.0985]}\end{array}$ & $\begin{array}{c}2.7775^{* * *} \\
{[0.0995]}\end{array}$ \\
\hline $\begin{array}{l}\text { Upper middle vs High } \\
\text { debt }\end{array}$ & $\begin{array}{c}2.1563 \\
{[0.1463]}\end{array}$ & $\begin{array}{c}3.0271^{* * *} \\
{[0.0860]}\end{array}$ & $\begin{array}{c}2.7368 * * * \\
{[0.1022]}\end{array}$ & $\begin{array}{c}2.7812 * * * \\
{[0.0996]}\end{array}$ \\
\hline
\end{tabular}


Table 3 (continued)

\begin{tabular}{|c|c|c|c|c|}
\hline & Mean & Median & $\begin{array}{c}\text { Winsorised } \\
\text { mean }\end{array}$ & $\begin{array}{c}\text { Trimmed } \\
\text { mean }\end{array}$ \\
\hline \multicolumn{5}{|c|}{ Panel I: Central and Eastern Europe countries } \\
\hline Low debt & $\begin{array}{c}2.2049 \\
(1.5204)\end{array}$ & $\begin{array}{c}2.6040 \\
(1.7897)\end{array}$ & $\begin{array}{c}2.5390 \\
(1.7621)\end{array}$ & $\begin{array}{c}2.5510 \\
(1.7679)\end{array}$ \\
\hline Lower middle debt & $\begin{array}{c}0.9039 \\
(0.6149)\end{array}$ & $\begin{array}{c}0.9065 \\
(0.6164)\end{array}$ & $\begin{array}{c}0.9065 \\
(0.6164)\end{array}$ & $\begin{array}{c}0.9065 \\
(0.6164)\end{array}$ \\
\hline Upper middle debt & $\begin{array}{c}0.8326 \\
(0.3934)\end{array}$ & $\begin{array}{c}0.8326 \\
(0.3934)\end{array}$ & $\begin{array}{c}0.8326 \\
(0.3934)\end{array}$ & $\begin{array}{c}0.8326 \\
(0.3934)\end{array}$ \\
\hline High debt & $\begin{array}{c}0.9111 \\
(1.0437)\end{array}$ & $\begin{array}{c}1.0988 \\
(1.2776)\end{array}$ & $\begin{array}{c}1.0988 \\
(1.2776)\end{array}$ & $\begin{array}{c}1.0988 \\
(1.2776)\end{array}$ \\
\hline $\begin{array}{l}\text { Low vs Lower middle } \\
\text { debt }\end{array}$ & $\begin{array}{c}0.3969 \\
{[0.5330]}\end{array}$ & $\begin{array}{c}0.6733 \\
{[0.4178]}\end{array}$ & $\begin{array}{c}0.6287 \\
{[0.4335]}\end{array}$ & $\begin{array}{c}0.6371 \\
{[0.4305]}\end{array}$ \\
\hline $\begin{array}{l}\text { Low vs Upper middle } \\
\text { debt }\end{array}$ & $\begin{array}{c}0.2861 \\
{[0.6069]}\end{array}$ & $\begin{array}{c}0.4758 \\
{[0.5093]}\end{array}$ & $\begin{array}{c}0.4442 \\
{[0.5235]}\end{array}$ & $\begin{array}{c}0.4501 \\
{[0.5208]}\end{array}$ \\
\hline Low vs High debt & $\begin{array}{c}0.5842 \\
{[0.4510]}\end{array}$ & $\begin{array}{c}0.7931 \\
{[0.3807]}\end{array}$ & $\begin{array}{c}0.7366 \\
{[0.3979]}\end{array}$ & $\begin{array}{c}0.7473 \\
{[0.3946]}\end{array}$ \\
\hline $\begin{array}{l}\text { Lower middle vs } \\
\text { Upper middle debt }\end{array}$ & $\begin{array}{c}0.0007 \\
{[0.9786]}\end{array}$ & $\begin{array}{c}0.0008 \\
{[0.9778]}\end{array}$ & $\begin{array}{c}0.0008 \\
{[0.9778]}\end{array}$ & $\begin{array}{c}0.0008 \\
{[0.9778]}\end{array}$ \\
\hline $\begin{array}{l}\text { Lower middle vs High } \\
\text { debt }\end{array}$ & $\begin{array}{l}1.96 \mathrm{E}-05 \\
{[0.9965]}\end{array}$ & $\begin{array}{c}0.0141 \\
{[0.9061]}\end{array}$ & $\begin{array}{c}0.0141 \\
{[0.9061]}\end{array}$ & $\begin{array}{c}0.0141 \\
{[0.9061]}\end{array}$ \\
\hline $\begin{array}{l}\text { Upper middle vs High } \\
\text { debt }\end{array}$ & $\begin{array}{c}0.0012 \\
{[0.9739]}\end{array}$ & $\begin{array}{c}0.0136 \\
{[0.9114]}\end{array}$ & $\begin{array}{c}0.0136 \\
{[0.9114]}\end{array}$ & $\begin{array}{c}0.0136 \\
{[0.9114]}\end{array}$ \\
\hline
\end{tabular}


Table 3 (continued)

\begin{tabular}{|c|c|c|c|c|}
\hline & Mean & Median & $\begin{array}{c}\text { Winsorised } \\
\text { mean }\end{array}$ & $\begin{array}{c}\text { Trimmed } \\
\text { mean }\end{array}$ \\
\hline \multicolumn{5}{|c|}{ Panel J: Transcaucasus and Central Asia countries } \\
\hline Low debt & $\begin{array}{c}4.8734 \\
(2.8782)\end{array}$ & $\begin{array}{c}4.8734 \\
(2.8782)\end{array}$ & $\begin{array}{c}4.8734 \\
(2.8782)\end{array}$ & $\begin{array}{c}4.8734 \\
(2.8782)\end{array}$ \\
\hline Lower middle debt & $\begin{array}{c}4.8458 \\
(4.2168)\end{array}$ & $\begin{array}{c}4.8149 \\
(4.2156)\end{array}$ & $\begin{array}{c}4.8149 \\
(4.2156)\end{array}$ & $\begin{array}{c}4.8149 \\
(4.2156)\end{array}$ \\
\hline Upper middle debt & $\begin{array}{c}6.0267 \\
(5.3240)\end{array}$ & $\begin{array}{c}6.0267 \\
(5.3240) \\
\end{array}$ & $\begin{array}{c}6.0267 \\
(5.3240) \\
\end{array}$ & $\begin{array}{c}6.0267 \\
(5.3240) \\
\end{array}$ \\
\hline High debt & $\begin{array}{c}3.7348 \\
(3.9114)\end{array}$ & $\begin{array}{c}3.7348 \\
(3.9114)\end{array}$ & $\begin{array}{c}3.7348 \\
(3.9114)\end{array}$ & $\begin{array}{c}3.7348 \\
(3.9114)\end{array}$ \\
\hline $\begin{array}{l}\text { Low vs Lower middle } \\
\text { debt }\end{array}$ & $\begin{array}{c}0.0007 \\
{[0.9786]}\end{array}$ & $\begin{array}{c}0.0007 \\
{[0.9786]}\end{array}$ & $\begin{array}{c}0.0007 \\
{[0.9786]}\end{array}$ & $\begin{array}{c}0.0007 \\
{[0.9786]}\end{array}$ \\
\hline $\begin{array}{l}\text { Low vs Upper middle } \\
\text { debt }\end{array}$ & $\begin{array}{c}0.2727 \\
{[0.6063]}\end{array}$ & $\begin{array}{c}0.2727 \\
{[0.6063]}\end{array}$ & $\begin{array}{c}0.2727 \\
{[0.6063]}\end{array}$ & $\begin{array}{c}0.2727 \\
{[0.6063]}\end{array}$ \\
\hline Low vs High debt & $\begin{array}{c}0.0854 \\
{[0.7739]}\end{array}$ & $\begin{array}{c}0.0854 \\
{[0.7739]}\end{array}$ & $\begin{array}{c}0.0854 \\
{[0.7739]}\end{array}$ & $\begin{array}{c}0.0854 \\
{[0.7739]}\end{array}$ \\
\hline $\begin{array}{l}\text { Lower middle vs } \\
\text { Upper middle debt }\end{array}$ & $\begin{array}{c}0.5644 \\
{[0.4598]}\end{array}$ & $\begin{array}{c}0.5679 \\
{[0.4595]}\end{array}$ & $\begin{array}{c}0.5679 \\
{[0.4595]}\end{array}$ & $\begin{array}{c}0.5679 \\
{[0.4595]}\end{array}$ \\
\hline $\begin{array}{l}\text { Lower middle vs High } \\
\text { debt }\end{array}$ & $\begin{array}{c}0.5273 \\
{[0.4870]}\end{array}$ & $\begin{array}{c}0.5264 \\
{[0.4874]}\end{array}$ & $\begin{array}{c}0.5264 \\
{[0.4874]}\end{array}$ & $\begin{array}{c}0.5264 \\
{[0.4874]}\end{array}$ \\
\hline $\begin{array}{l}\text { Upper middle vs High } \\
\text { debt }\end{array}$ & $\begin{array}{c}2.3952 \\
{[0.1590]}\end{array}$ & $\begin{array}{c}2.3952 \\
{[0.1590]}\end{array}$ & $\begin{array}{c}2.3952 \\
{[0.1590]}\end{array}$ & $\begin{array}{c}2.3952 \\
{[0.1590]}\end{array}$ \\
\hline
\end{tabular}

Notes:

In the ordinary brackets below the parameter estimates are the corresponding $t$-statistics based on Newey and West (1987) standard errors.

$\mathrm{XX} v s . \mathrm{XX}$ are equality tests.

In the square brackets we report the associated $p$-values are given. $*, * *$ and $* * *$ indicate significance at $1 \%, 5 \%$, and $10 \%$ respectively. 